\title{
Mid-Holocene Littorina Sea transgressions based on stratigraphic studies in coastal lakes of NW Russia
}

\author{
PER SANDGREN ${ }^{1}$, DMITRY A. SUBETTO ${ }^{2}$, BJÖRN E. BERGLUND ${ }^{1}$, NATALIA N. DAVYDOVA ${ }^{2}$ and \\ LARISSA A. SAVELIEVA ${ }^{3}$
}

Sandgren, P., Subetto, D.A., Berglund, B.E., Davydova, N.N.\& Savelieva, L.A., 2004: Mid-Holocene Littorina Sea transgressions based on stratigraphic studies in coastal lakes of NW Russia. GFF, Vol. 126 (Pt. 4, December), pp. 363-380. Stockholm. ISSN 1103-5897.

\begin{abstract}
The mid-Holocene Littorina Sea transgression has been studied in sediment cores from four coastal lakes in NW Russia. The basins are situated in the same drainage system at elevations from 6.9 to $9.2 \mathrm{~m}$ a.s.l. Complementary parameters have been applied to identify water-level changes. Chronological models are based on AMS radiocarbon dating of bulk sediments but also wood remains and moss sedge peat has been dated in a few cases. All radiocarbon ages have been calibrated to calendar years BP (cal. BP). Between 8000 and 6000 cal. BP the present-day lakes were in contact with the Littorina Sea and brackish conditions prevailed. The water level was higher than $6 \mathrm{~m}$ a.s.l. clearly documented in all four basins. A peak reaching above the level of the uppermost lake (9.2 $\mathrm{m}$ a.s.l.) has been dated to ca. 7500 cal. BP. During the high level phase a short lived regression/transgression is recognized in all but the uppermost basin. This minor water level fluctuation lasted for a few hundred years around $7000 \mathrm{cal}$. BP. It is reflected in various parameters in the different basins. Correlations are made with recent studies from Blekinge in southeastern Sweden situated at the $10 \mathrm{~m}$ Littorina isobase as the present investigation area. The parallel Littorina Sea history in these two areas seems to confirm a multi-transgression pattern across the southern Baltic Sea.
\end{abstract}

Keywords: mid-Holocene transgression, Littorina Sea, Baltic Sea, Gulf of Finland, NW Russia, magnetic stratigraphy, diatom stratigraphy, climate/sea-level interaction.

${ }^{1}$ Department of Geology/Quaternary Sciences, GeoBiosphere Science Centre, Lund University, Sölvegatan 12, SE-22362 Lund; per.sandgren@geol.lu.se

${ }^{2}$ Institute of Limnology, Russian Academy of Sciences, Sevastyanova 9, St. Petersburg 196105, Russia

${ }^{3}$ Institute of Geography, St. Petersburg State University, Sredny 41, St. Petersburg 199004, Russia

Manuscript received 15 July 2004. Revised manuscript accepted 25 November 2004.

\section{Introduction}

Relative sea level (RSL) changes since the deglaciation in North Europe depend on two main factors: 1) glacial rebound of the earth crust (glacio-isostasy), 2) ice-volume related sea-level changes (glacio-eustasy). Variations of the ocean's volume associated with the thermal conditions of the upper water column as well as regional and local climatic factors can to some extent also be of importance. In areas situated in a distal position with respect to the maximum ice load, the RSL during mid-Holocene is assumed to have been highly influenced by the global eustatic component. Because of the palaeoclimatic implications of such variations the magnitude and timing of these eustatic sea level changes are important to decipher. Therefore we initiated a collaboration program along a Baltic Sea transect in areas with comparable isostatic uplift, approximately along the $10 \mathrm{~m}$ isobase to study the mid-Holocene so-called Littorina transgression. Areas (and scientists) involved are Sjælland, E Denmark (Charlie Christensen), Blekinge, SE Sweden (Berglund, Sand- gren, Yu) and the St. Petersburg area including Ingermanland, NW Russia (Subetto, Berglund, Sandgren). Earlier studies in southern Scandinavia have shown a multitransgressive pattern for the Littorina Sea (Berglund 1964, 1971; Mörner 1969; Digerfeldt 1975; Liljegren 1982; Christensen 1995). However, Finnish colleagues have questioned the occurrence of several transgressions based on studies in SE Finland and NW Russia (Eronen 1974; Hyvärinen 1991; Miettinen 2002). Our aim has been to detect, document, and date the transgression pattern and compare the development between several sites in the different areas and between the different regions along the transect. In this paper we present results from four lakes in the coastal area west of St. Petersburg, Ingermanland (IN). We also summarize previous studies on the Karelian Isthmus (KI) situated NW of St. Petersburg (Fig. 1A). Our study is concentrated to the maximum transgression phase between 8000 and 6000 calendar years BP. 


\section{Previous studies of the Littorina}

\section{Sea in the St. Petersburg region}

Shoreline studies of the Littorina Sea in the eastern part of the Gulf of Finland were conducted already at the end of the $19^{\text {th }}$ century (De Geer 1894; Berghell 1896) and in the beginning of the $20^{\text {th }}$ century (Ailio 1915). Ramsay (1920) compiled the results of these first investigations. He also presented isobases for the Littorina Sea around the Gulf. According to Ramsay (1920) the $10-\mathrm{m}$ isobase extended from southwest to northeast, diagonally across the Gulf, through Krasnaja Gorka on the south coast to the southeastern end of the island of Kronstadt and Lisij Nos on the northeastern coast. He concluded that the isostatic gradient of the Littorina limit was $1.3 \mathrm{~m} / 10 \mathrm{~km}$ in this area. Two transgression phases could be identified; an older one dated to $6500{ }^{14} \mathrm{C}$ years $\mathrm{BP}$ (ca. 7400 cal. BP, radiocarbon dates in the older literature have been calibrated to calendar years BP according to Stuiver et al. 1998 to facilitate comparison with calibrated dates from sites presented in this paper) and a younger one dated to 4250 ${ }^{14} \mathrm{C}$ years BP (ca. 4900 cal. BP). During the youngest transgression the Littorina Sea reached approximately $+8 \mathrm{~m}$, a similar altitude as documented in Blekinge in southeast Sweden (Ramsay 1926). In the St Petersburg's area, which also was situated around the $10-\mathrm{m}$ isobase the highest salinity was contemporaneous with the highest sea level. The last 6000 years have been characterized by a gradual regression (Markov 1931, 1934).

On the basis of morphological and lithostratigraphical studies carried out in southern Finland and in the Karelian Isthmus, Hyyppä $(1932,1937)$ distinguished altogether four Littorina transgressions (LI-LIV). The highest levels of the Littorina Sea were, according to Hyyppä, about $+20 \mathrm{~m}$ near Viborg, $+17 \mathrm{~m}$ near Somme (Popovo) and $+12-16 \mathrm{~m}$ in the area of Luzhki (Karjalainen).

In Kondrat'evo west of Viborg and in Hairi east of Viborg Littorina sediments represented by gyttja have been found at levels from 18.6 to 17.9 and from 16.8 to $15.6 \mathrm{~m}$ a.s.1., respectively (Kleymenova et al. 1988). Gyttja at both sites was overlain by peat, which has been radiocarbon dated to $4610 \pm 150$ and $3430 \pm 60{ }^{14} \mathrm{C}$ years BP (15.6 m a.s.l., 5593-4872 cal. BP and $18.7 \mathrm{~m}$ a.s.1., 3834-3480 cal. BP, respectively). Kleymenova and co-authors (1988) assumed that two transgressive phases could be identified in the Hairi section and a single one in the Kondrat'evo section. The difference may be due to the fact that the Hairi site is situated near the head of a long and narrow bay, while the Kondrat'evo site is more exposed to the sea.

In the region of the Tchernaya River section, where the Littorina maximum is estimated to $13 \mathrm{~m}$ a.s.l., four Littorina terraces (at 1.5, 4.0, 8.0-9.0 and 13.0-14.0 $\mathrm{m}$ a.s.l.) can be distinguished. The stratigraphy includes two layers of Littorina sediments. A lower unit (from 7.8 to 9.1 $\mathrm{m}$ a.s.l.) consists of gyttja with thin layers of peat and an upper unit (from 9.1 to 9.9 $\mathrm{m}$ a.s.1.) consist of horizontally laminated sand (Znamenskaya et al. 1980). Samples

Table 1. Lake characteristics.

\begin{tabular}{lccccc}
\hline Site & Longitude & Latitude & $\begin{array}{c}\text { Altitude } \\
\mathrm{m} \text { a.s.l. }\end{array}$ & $\begin{array}{c}\text { Water } \\
\text { depth, } \mathrm{m}\end{array}$ & $\begin{array}{c}\text { Surface } \\
\text { area, } \mathrm{km}^{2}\end{array}$ \\
\hline Lake Babinskoye & $59^{\circ} 36^{\prime} .9 \mathrm{~N}$ & $28^{\circ} 36^{\prime} .9 \mathrm{E}$ & 6.9 & $\sim 2$ & 7 \\
Lake Leshy & $59^{\circ} 38^{\prime} .0 \mathrm{~N}$ & $28^{\circ} 27^{\prime} .2 \mathrm{E}$ & 7.6 & $\sim 2$ & 0.21 \\
Lake Khabalovskoye & $59^{\circ} 37^{\prime} .0 \mathrm{~N}$ & $28^{\circ} 29^{\prime} .1 \mathrm{E}$ & 6.7 & $\sim 2$ & 5.5 \\
Lake Glubokoye & $59^{\circ} 41^{\prime} .2 \mathrm{~N}$ & $28^{\circ} 40^{\prime} .0 \mathrm{E}$ & 9.2 & 22 & 5.7 \\
\hline
\end{tabular}

Table 2. Analyses performed of the sediment cores from Lake Babinskoye (LB), Lake Leshy (LL), Lake Khabalovskoye (LK) and Lake Glubokoye (LG).

\begin{tabular}{lcccccc}
\hline Core & $\begin{array}{c}\text { Radio } \\
\text {-carbon }\end{array}$ & $\begin{array}{c}\text { Total } \\
\text { organic } \\
\text { carbon }\end{array}$ & Magnetic & $\begin{array}{c}\text { Plant } \\
\text { macro fossil }\end{array}$ & Diatom & Pollen \\
\hline LB1-98 & $\mathrm{x}$ & $\mathrm{x}$ & $\mathrm{x}$ & - & $\mathrm{x}$ & $\mathrm{x}$ \\
LB1-01 & $\mathrm{x}$ & $\mathrm{x}$ & $\mathrm{x}$ & - & - & $\mathrm{x}$ \\
LB2-01 & $\mathrm{x}$ & - & $\mathrm{x}$ & $\mathrm{x}$ & $\mathrm{x}$ & $\mathrm{x}$ \\
LL3-01 & $\mathrm{x}$ & - & - & $\mathrm{x}$ & $\mathrm{x}$ & $\mathrm{x}$ \\
LK1-03 & $\mathrm{x}$ & - & - & - & - & - \\
LG1-03 & $\mathrm{x}$ & - & $\mathrm{x}$ & - & $\mathrm{x}$ & \\
\hline
\end{tabular}

* Diatom analyses from Miettinen (2002)

from the peat layers have been radiocarbon dated resulting in ages within the time span 8300-6700 cal. BP.

A sample from a layer of buried peat underlying Littorina sediments in St. Petersburg has been radiocarbon dated to $6060 \pm 70{ }^{14} \mathrm{C}$ years B.P. $(7093-6728 \mathrm{cal}$. BP). There are two Littorina terraces in the St. Petersburg region, within the interval 6-4 and 3-0 $\mathrm{m}$ a.s.l. Littorina sediments consisting of laminated clay with abundant plant remains underlying gyttja (from -1.65 to $+1.15 \mathrm{~m}$ above the river level) have been found in the open section "Nevsky Lesopark", 4 km southeast of St. Petersburg. A radiocarbon date from the gyttja (0.85-0.95 $\mathrm{m}$ above river level) yielded $5750 \pm 50$ yr B.P. (6715-6411 cal. BP) according to Malakhovsky et al. (1989).

It can be concluded that according to these early studies the maximum Littorina transgression reached c. $10 \mathrm{~m}$ a.s.l. around 7000 cal. BP in the easternmost part of the Gulf of Finland (cf. Dolukhanov 1979). There are also several indications of two or more transgressions but these are not well dated and have not unambiguously been proven.

Recently Miettinen (2002) has studied several sites along the coast of the Gulf of Finland. He concluded that the Littorina Sea reached a maximum level of ca. $12 \mathrm{~m}$ a.s.l. on the Karelian Isthmus and c. $10 \mathrm{~m}$ a.s.l. in the Luga-Narva Lowland (Ingermanland) to the west around $7000 \mathrm{cal}$. BP. According to Miettinen (2002) the diatom analyses from these sites are interpreted in terms of one transgression.

\section{Study area}

The studied sites Lake Babinskoye (LB), Lake Leshy (LL), Lake Khabalovskoye (LK) and Lake Glubokoye (LG) are located in the Luga-Narva Lowland, between the Baltic Clint and the present-day southern shoreline of the Gulf of Finland, c. 100 $\mathrm{km}$ west of St. Petersburg (Fig. 1, for lake characteristics see Table 1). The LugaNarva Lowland or the Narva-Luga Clint Bay are named after two major rivers, River Narva and River Luga, which drain the area in the south and southeast into bays with the same names. River Narva is the natural boundary between Russia and Estonia. The lowland is contoured to the south and to the east by the Baltic Clint which is the pre-Quaternary Quest devel- 
oped in sandstones of Lower Cambrian age and calcareous deposits (limestone, dolomite, marl) of Lower Ordovician age overlain by Quaternary sediments, dominated by till. The clint reaches $75-80 \mathrm{~m}$ a.s.l. and is up to $5-8 \mathrm{~km}$ wide.

Most of the studied lakes are shallow, with exception for Lake Glubokoye with a maximum depth of $22 \mathrm{~m}$. The main site, Lake Babinskoye (LB), is situated in a NNE to SSW trending valley that is a part of an over-deepened late-glacial erosion valley (Malakhovsky \& Markov 1969). The depression is cut into Quaternary sediments of more than $30 \mathrm{~m}$. The thickness of late and postglacial deposits in the central northern part of the lake is according to our investigations more than $20 \mathrm{~m}$.

During the Baltic Ice Lake stage the highest shoreline reached c. 35-40 m a.s.l. The Ancylus Lake and the Littorina Sea transgression reached their highest level between c. 9 and $10 \mathrm{~m}$ a.s.l. respectively according to studies in adjacent Estonia (Lepland et al. 1996). The salinity in the Gulf of Finland outside our study area is today c. 3-4\%o, an environmental factor of importance for the interpretation of salinity changes in the past.

\section{Material and methods}

\section{Coring}

A core from the centre of the northern part of LB was collected from the ice in spring 1998 (core LB1-98, located at point A in Fig. 1C). A second core from the same location was collected in spring 2001 (core LB1-01). Core LB1-98 and LB1-01 have identical stratigraphies and can in fact be considered as one core. In addition another 4 cores (Cores LB2-01 to LB5-01) have been collected along a transect from core LB1-98/01 into the northern bay (A-B in Fig. 1C). During the field campaign in 2001 seven cores were collected from LL along an E-W trending transect (LL1-01 to LL7-01, C-D in Fig. 1C) across the entire lake. A complementary field expedition was organized in 2003 in order to core LG and LK. All cores were collected with a strengthened $1 \mathrm{~m}$ long Russian corer (inner diameter 5 and $7.5 \mathrm{~cm}$ ). Preliminary lithostratigraphic descriptions of the cores were carried out in the field and the different layers correlated between the coring sites along the transects. The cores were wrapped in

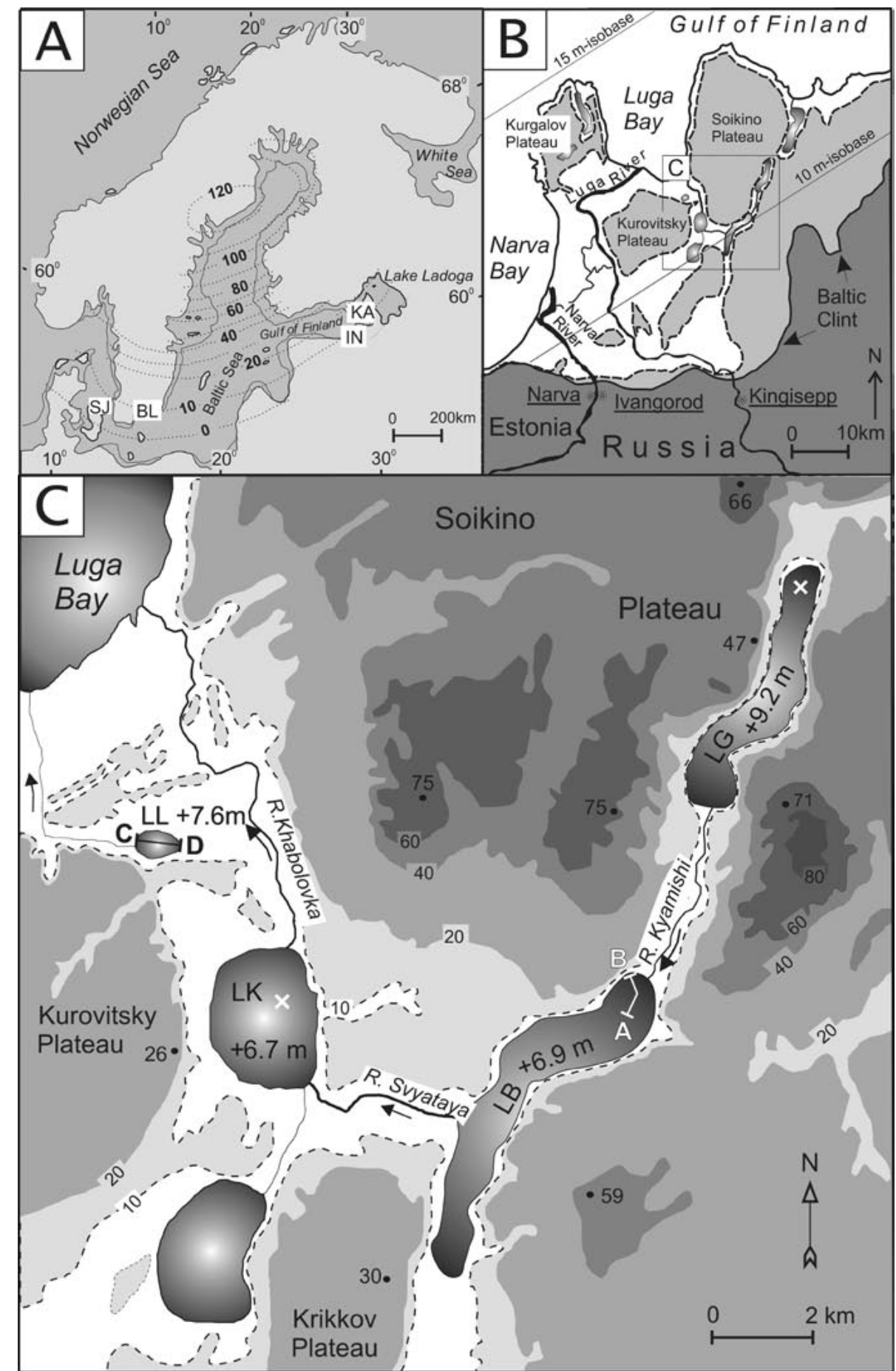

Fig. 1. Location of the study area in the eastern part of the Gulf of Finland. A. The Baltic during the Littorina Sea stage with the highest shoreline and isobases (after Eronen 1988). Abbreviations: SJ - Själland, Denmark; BL - Blekinge, SE Sweden; IN - Ingermanland area, NW Russia; KA - Karelian Isthmus, NW Russia. B. The Ingermanland area where the dashed line marks the highest Littorina Sea shoreline, 10 and $15 \mathrm{~m}$ isobases according to Markov (1931). White $(<10$ $\mathrm{m}$ ) and light grey areas represent the Luga-Narva Lowland and dark grey areas above the clint. C. Close up of the investigation area with topography and studied lakes, LG - Lake Glubokoye (9.2 $\mathrm{m}$ a.s.1.), LB - Lake Babinskoye (6.9 m a.s.1.), LK - Lake Khabalovskoye (6.7 m a.s.1.), LL - Lake Leshy (7.6 m a.s.1.). Transects where a number of cores were collected are labelled A-B (in LB) and C-D (in LL). For LK and LG the coring site is indicated by a cross. Note the system of dunes NW of LL as indirectly reflected by the $10 \mathrm{~m}$ contour line. 


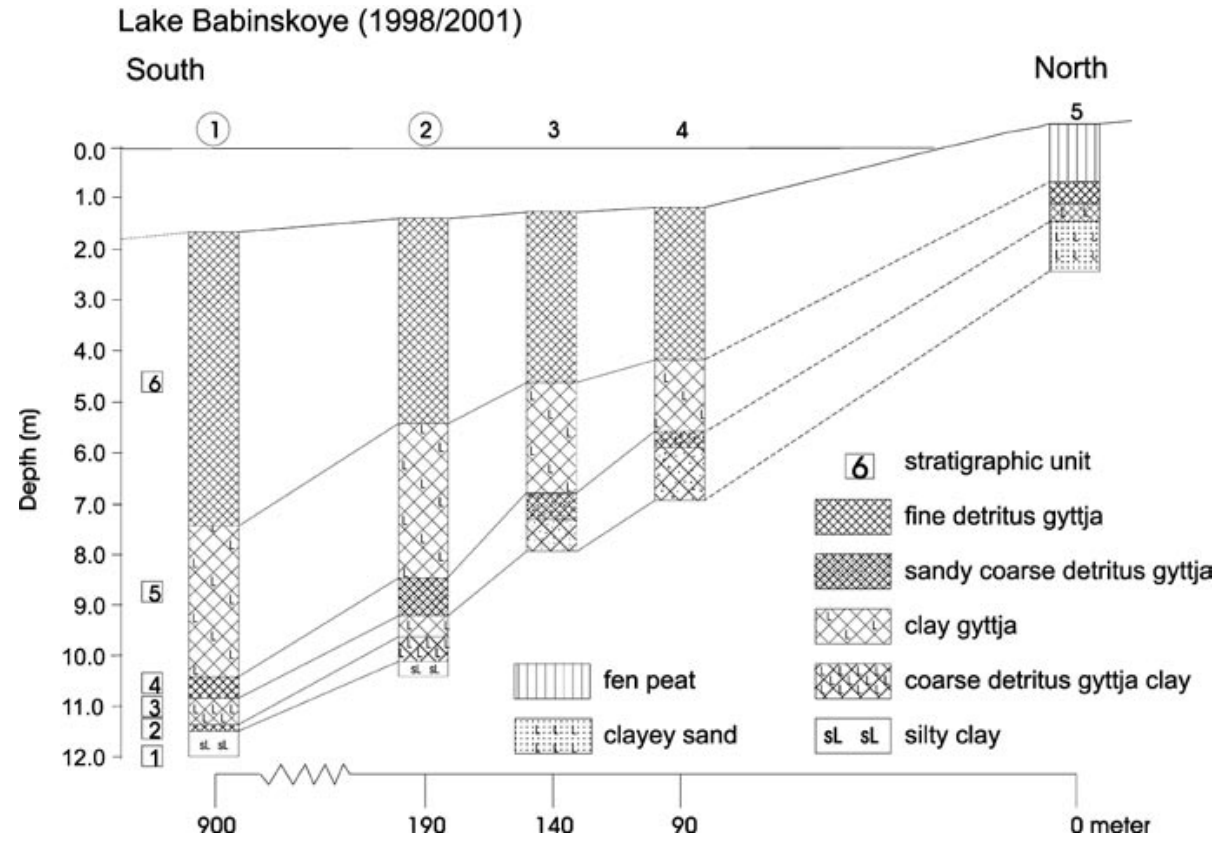

Fig. 2. Transect of cores from the centre of the northern part of Lake Babinskoye to the shore (corresponding to A-B in Fig. 1C). Stratigraphic units 1-6 according to Tables 3 and 4 . Note that the silty clay in unit 1 continues as a varved clay to a depth of at least $20 \mathrm{~m}$. S - south, $\mathrm{N}$ - north.

plastic, placed in D-shaped plastic liners and carefully transported to the Institute of Limnology in St. Petersburg and to the Department of Geology in Lund, where they were stored at $4^{\circ} \mathrm{C}$ in a cold-room until analyzed. The sediment cores were described in detail and correlated using lithological marker horizons in the laboratory. Analyses performed on the different cores are shown in Table 2.

\section{Mineral magnetic and carbon analy- ses}

All cores were initially scanned for magnetic susceptibility using a Bartington susceptibility bridge with a MS2E1 highresolution scanning sensor attached to an automatic core-logging device(Tamiscan). Readings were taken every $4 \mathrm{~mm}$ with an air reading in between every measurement. After this procedure the fresh sediment in core LB1-98, LB1-01, and core LL3-01 were contiguously sub-sampled by gently pushing $7 \mathrm{~cm}^{3}$ polystyrene boxes $(22 \times 22 \times 22 \mathrm{~mm})$ into the cleaned sediment surface. Initial (low-field) magnetic susceptibility $(\chi)$ was measured with a Geofyzica Brno KLY2 Kappa Bridge. Anhysteretic Remanent Magnetisation (ARM) was induced using a Molspin AF demagnetiser in a peak alternating field organic carbon content. The carbon emitted between 105 and $550^{\circ} \mathrm{C}$ is interpreted as the organic carbon fraction and the carbon emitted between 550 and $950^{\circ} \mathrm{C}$ is interpreted as the inorganic fraction.

\section{Pollen analysis}

Samples for pollen analysis were taken from the cores at $5-10 \mathrm{~cm}$ intervals with a volume of $1 \mathrm{~cm}^{3}$ and prepared using standard techniques (Berglund \& RalskaJasiewiczowa 1986). Pollen and spore identification were carried out using published references (Kupriyanova and Alyoshina 1972; Moore et al. 1991) and reference collections at the Department of Geology at Lund University and the Institute of Geography in St. Petersburg State University. In each sample 400-600 terrestrial pollen grains were counted. The TILIA2 and TILIA GRAPH2 programs (Grimm 1991) were used to plot pollen diagrams. The total pollen sum was calculated as the sum of tree, dwarf shrub and herb pollen. Stratigraphically constrained incremental sum of squares cluster analysis was performed using the CONISS program (Grimm 1987) as a guideline for zonation of the diagrams into local pollen assemblage zones (LPAZ). of $0.1 \mathrm{mT}$. Magnetic saturation at room temperature was achieved by exposing the samples to a 1 Tesla (T) magnetic field in a Redcliff 700 BSM magnetiser. The induced remanence was measured with a Molspin Minispin magnetometer. The samples were then exposed to consecutive reversed magnetic fields in $10 \mathrm{mT}$ steps, starting at $20 \mathrm{mT}$ using a Molineux Pulse Magnetic Charger. The decreasing magnetization was again measured on the magnetometer and the procedure continued until magnetization reversed and the backcoercivity of remanence $\left(\left(\mathrm{B}_{0}\right)_{\mathrm{CR}}\right)$ could be determined. Finally all samples were magnetised in reversed fields of 100 and $300 \mathrm{mT}$ to allow calculation of the $\mathrm{S}_{-100}$ and $\mathrm{S}_{-300}$-ratio (IRM ${ }_{-100 \mathrm{mT}} / \mathrm{SIRM}$ and IRM $_{-300 \mathrm{mT}} / \mathrm{SIRM}$ ). After completion of the magnetic analysis the samples were oven dried at $50^{\circ} \mathrm{C}$ and the dry mass calculated to express the magnetic parameters on a mass specific basis. Every second of the dried samples was then remagnetized in the $1 \mathrm{~T}$ field and the new induced remanence measured. Finally the backcoercivity of the dried samples was determined as well as the magnetization after exposure to the -100 and $-300 \mathrm{mT}$ fields.

A LECO RC-412 multiphase carbon determinator was used to measure the total

\section{Plant macrofossil analysis}

Plant macrofossil analysis was carried out using the general guidelines of Wasylikowa (1986). Numbers of fossils found are expressed per unit volume (50 $\mathrm{ml}$ ). Local macrofossil assemblage zones (LMAZ) were distinguished on the basis of constrained cluster analysis (CONISS, Grimm 1987), considering terrestrial as well as wetland plants. Material from selected levels was after identification in some cases used for radiocarbon dating.

\section{Diatom analysis} pared according to standard methods (Davydova 1985; Battarbee 1986). The diatom taxonomy used here follows that of Hustedt (1930) and Krammer \& LangeBertalot (1986-1991). In addition to our analyses from core LB2-01, LL3-01 and LG1-03 diatom data from LB1-98 was provided by Miettinen (2002). In each sample 200-300 diatom frustules were identified. The halobian system used in the diatom diagrams is based on the salinity tolerance scheme of Simonsen (1962). The diatom flora is classified into three
Samples for diatom analysis were pre- 
A Lake Babinskoye, core LB1-98/01

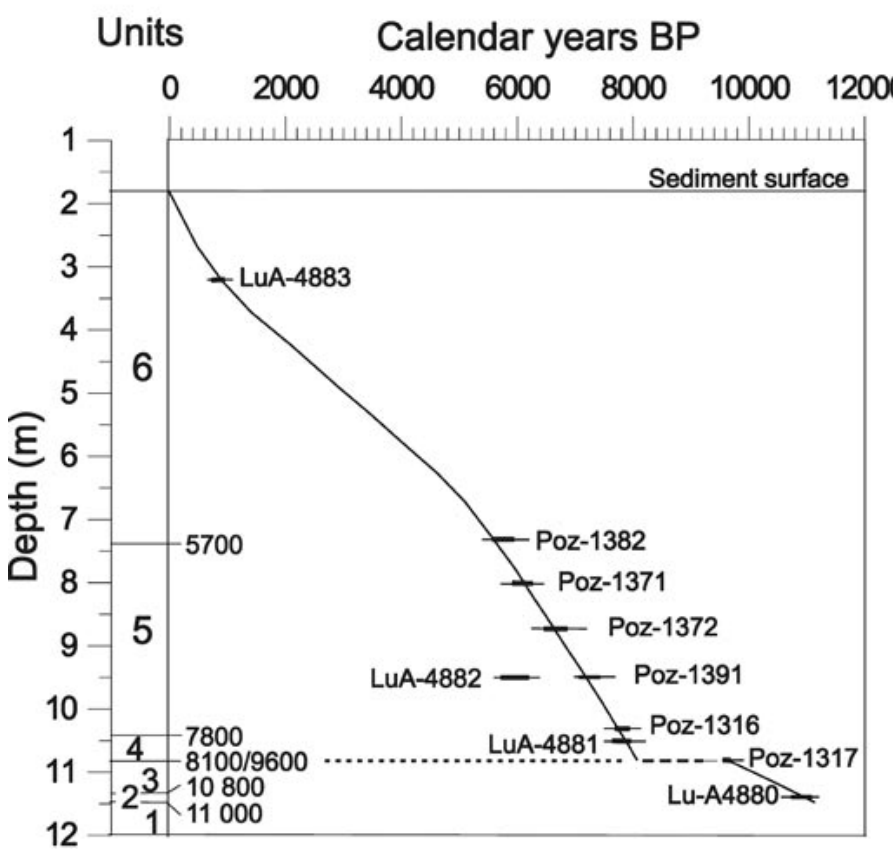

B Lake Babinskoye, core LB2-01

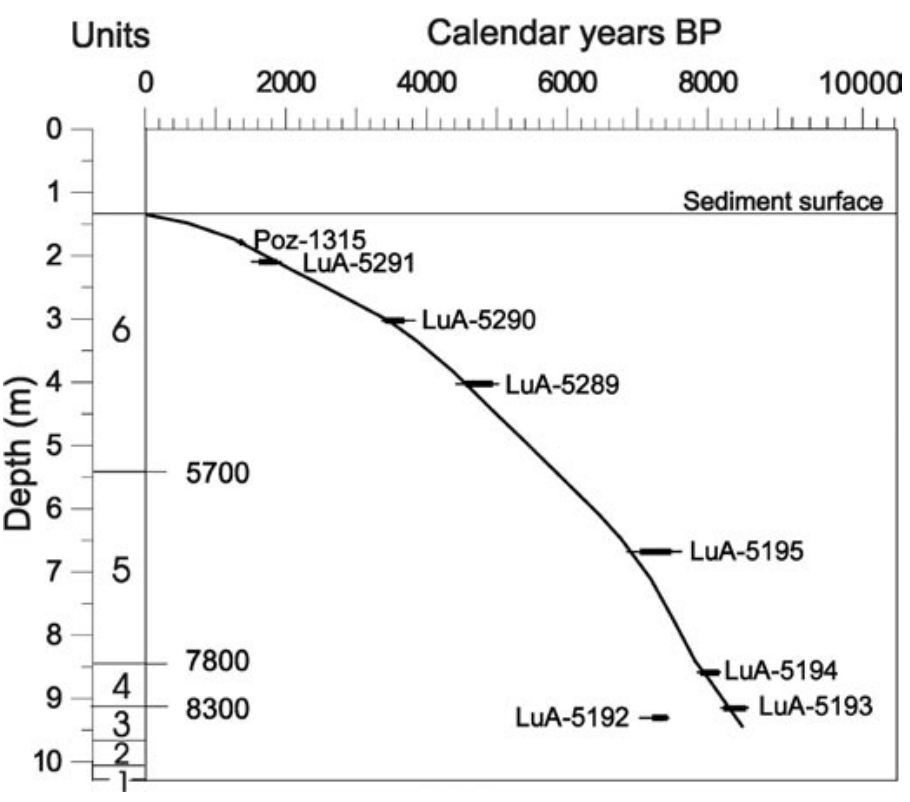

Fig. 3. A. Time-depth model for core LB1-01. B. Time-depth model for core LB2-01. Inferred ages (cal. BP) of important stratigraphic transitions are also shown. Radiocarbon ages are presented in the Appendix.

ecological groups by salinity preferences: mesohaline (salinity tolerance 20-5\%o), oligohaline (tolerance 5-0.5\%o) and freshwater species.

\section{AMS ${ }^{14} \mathrm{C}$ dating and age models}

Radiocarbon ages were determined by accelerator mass spectrometry (AMS). Because of the low content of terrestrial plant macrofossil remains in the sediments in LB, LL and LG bulk sediment samples were used. In addition two wood fragments found in the sediment in Lake Leshy were also dated. In Lake Khabalovskoye dating was based on moss sedge peat and a wood fragment. In total 32 samples have been dated (15 at the Radiocarbon Laboratory at Lund University, 17 samples at the Poznan Radiocarbon Laboratory). All dates are presented in the Appendix. Intcal98 (Stuiver et al. 1998) was used to convert the radiocarbon ages of limnic sediments to calendar years before present (cal. BP). Samples originating from Littorina Sea sediments have been calibrated according to a combination of Intcal98 and Marine98 (Stuiver et al. 1998) with data from the Gulf of Finland (Olsson
Table 3. Sediment description for core LB1-98 and LB1-01.

\begin{tabular}{rcl}
\hline $\begin{array}{r}\text { Depth below } \\
\text { water level }(\mathrm{m})\end{array}$ & Units & Stratigraphic description \\
\hline $0-1.85$ & & Water \\
$1.85-7.40$ & 6 & Dark brown green, homogeneous, slightly clayey fine detritus gyttja \\
$7.40-10.40$ & 5 & Dark greenish brown, faintly laminated clayey fine detritus gyttja \\
$10.40-10.80$ & 4 & Dark brown coarse detritus gyttja, below 10.70 slightly silty/sandy \\
$10.80-11.31$ & 3 & Gyttja clay \\
$10.80-10.95$ & $3 \mathrm{~b}$ & Greenish grey gyttja clay \\
$10.95-11.31$ & $3 \mathrm{a}$ & Grey, FeS coloured gyttja clay \\
$11.31-11.47$ & 2 & Gyttja clay and gyttja \\
$11.31-11.36$ & $2 \mathrm{c}$ & Greenish grey gyttja clay \\
$11.36-11.41$ & $2 \mathrm{~b}$ & Black grey coarse detritus gyttja \\
$11.41-11.47$ & $2 \mathrm{a}$ & Grey gyttja clay \\
$11.47-20.00+$ & 1 & Grey, FeS coloured laminated silty clay \\
\hline
\end{tabular}

Table 4. Sediment description for core LB2-01.

\begin{tabular}{|c|c|c|}
\hline $\begin{array}{r}\text { Depth below } \\
\text { water level }(\mathrm{m})\end{array}$ & Units & Stratigraphic description \\
\hline $0-1.37$ & & Water \\
\hline $1.37-5.38$ & 6 & Darkbrown, homogeneous fine detritus gyttja \\
\hline $5.38-8.45$ & 5 & Dark green, slightly laminated, slightly silty, fine detritus gyttja \\
\hline $8.45-9.20$ & 4 & Detritus gyttja \\
\hline $8.45-8.80$ & $4 b$ & Dark brown green, slightly fine sandy, coarse detritus gyttja \\
\hline $8.80-9.20$ & $4 \mathrm{a}$ & Dark grey green sandy coarse detritus gyttja \\
\hline $9.20-9.64$ & 3 & $\begin{array}{l}\text { Light grey - grey clay gyttja/gyttja clay with dark brown drift peat layers } \\
\text { between } 9.53 \text { and } 9.64 \mathrm{~cm}\end{array}$ \\
\hline $9.64-9.85$ & 2 & Black, slightly clayey coarse detritus gyttja \\
\hline $9.85-10.39$ & 1 & Clay and sand \\
\hline $9.85-10.16$ & $1 \mathrm{~b}$ & Dark grey green gyttja clay \\
\hline $10.16-10.39+$ & $1 \mathrm{a}$ & Grey silty sand, laminated \\
\hline
\end{tabular}


Lake Babinskoye, core LB1 -01

Mineral magnetic parameters and organic content

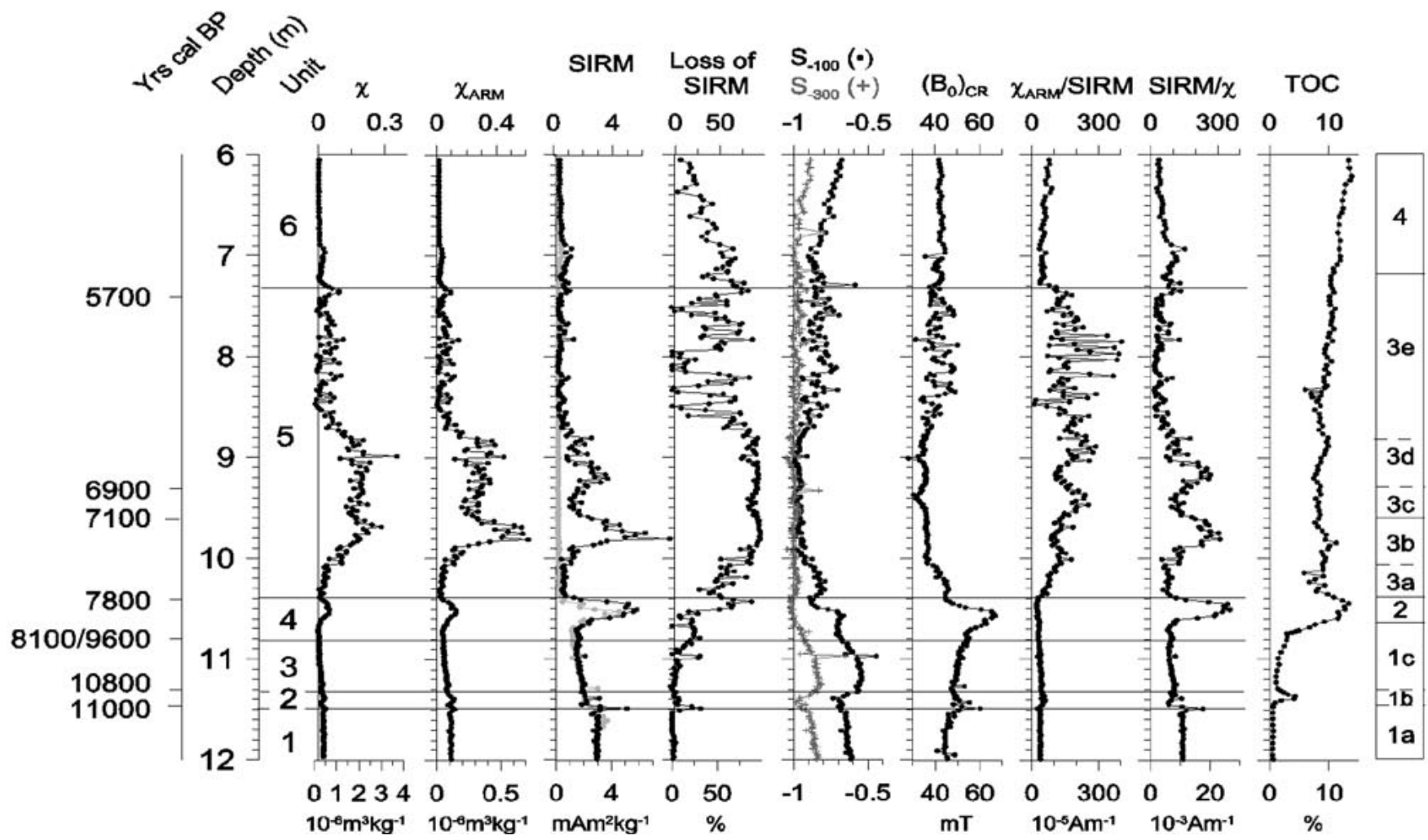

Fig. 4. Mineral magnetic parameters and interparamagnetic ratios from core LB1-01. Black curves (with black dots) refer to measurements performed on the naturally wet sediment and dark grey curves (with crosses) refer to measurements on the dried samples. Chronology based on Fig. $3 \mathrm{~A}$, stratigraphic units from Table 3. Zonation based on magnetic characteristics is also shown.

1980). These refer to the deeper waters in the Gulf with a present day salinity of $7-8 \%$ while coastal areas in the Narva region have a salinity of 3-4\% (Pertilä \& Savchuk 1996). The diatom assemblages in the lagoons of Littorina Sea studied in this investigation indicates a salinity of $6-8 \%$ in such coastal environments. To compensate for the high salinity in the marine dataset this has only been taken into account to $50 \%$ while the remaining $50 \%$ of the calibration is based on the atmospheric dataset. Age models have been constructed based on the calibrated ages. Calibrated ages with $2 \sigma$ are plotted in each diagram.

\section{Results}

\section{Lake Babinskoye (6.9 m a.s.l.)}

Stratigraphy and chronology. - Based on core LB1-98/-01, centrally situated in the northern part of the lake, 6 stratigraphic units were identified, some of which could be further subdivided (Table 3 ). The uniformity and wide lateral extension of these units are clearly reflected in the

Table 5. Inferred ages of stratigraphic transitions in core LB1-98 and LB2-01 based on the time depth model in Fig. 3A and B, respectively.

\begin{tabular}{lcr}
\hline Transition & \multicolumn{2}{c}{ Age cal. BP } \\
& LB1-98 & LB2-01 \\
\hline Unit $5 / 6$ & 5700 & 5700 \\
Unit $4 / 5$ & 7800 & 7800 \\
Unit $3 / 4$ & $8100 / 9600$ & 8300 \\
Unit $2 / 3$ & 10800 & - \\
Unit $1 / 2$ & 11000 & - \\
\hline
\end{tabular}

stratigraphic transect (Fig. 2). The brackish sediment of the Littorina transgression layer (unit 5) is undoubtedly recognized as faintly laminated, clayey fine detritus gyttja. The organic sequence terminates at $11.47 \mathrm{~m}$ below the water level. Below this level there is c. $8 \mathrm{~m}$ of varved clay (not shown in Fig. 2).

The sediment in core LB1-98/01 was dated by 10 radiocarbon dates and LB201 was dated by 8 dates (Appendix). Based on the calibrated ages a time/depth model was constructed for each core (Fig. 3A and B), which confirms that the boundaries between stratigraphic units are practically synchronous (Table 5). The radiocarbon dates in core LB1-98/01 indicate that there is a hiatus at the unit $3 / 4$ transition. Erosion in the upper part of unit 3 is supported by the fact that the coarse detritus gyttja in unit 4 is slightly sandy and silty in the lower $10 \mathrm{~cm}$. If we assume a constant sedimentation rate in unit 4 and 
3 the eroded sediment in the top of unit 3 corresponds to a hiatus of c. 1500 years. Although there are no dates below the unit 3/4 boundary in core LB2-01 we assume a corresponding hiatus in this core, a fact that is supported by the pollen analytical correlations (see below).

Mineral magnetic and organic carbon analyses. - Based on the mineral magnetic analyses core LB1-01 has been subdivided into 4 main magnetic units of which the magnetic boundaries more or less coincide with stratigraphic boundaries (Fig. 4).

Magnetic unit $1(12.00-10.70 \mathrm{~m})$. This unit corresponds to the three lowermost stratigraphic units and displays low and slightly decreasing $\chi, \chi_{\mathrm{ARM}}$ and SIRM values. Except for in unit $1 \mathrm{bS}_{-300}$ ratios do not entirely reverse to -1 but vary between $\mathrm{c}$. -0.8 and -0.9 , which indicates the presence of a hard magnetic component in unit $1 \mathrm{a}$ and $1 \mathrm{c} . \chi_{\mathrm{ARM}} / \mathrm{SIRM}$ ratios of around 50 $10^{-5} \mathrm{Am}^{-1}$ reflect a detrital origin of the magnetic grains, which is dominated by multidomain grains as indicated by the $\mathrm{SIRM} / \chi$ ratios around $1010^{-3} \mathrm{Am}^{-1}$. Practically all the dry SIRM values are identical as to those measured on the wet ones. TOC values are $<2 \%$, apart from the spike in unit $1 \mathrm{~b}$ that reach $\sim 4 \%$.

Magnetic unit 2 (10.70-10.40). It is characterized by a distinct peak in magnetic concentration parameters and in $\mathrm{SIRM} / \chi$ ratios $\left(\sim 2510^{-3} \mathrm{Am}^{-1}\right)$. The dry SIRM values are lower compared to the naturally wet ones. $\left(\mathrm{B}_{0}\right)_{\mathrm{CR}}$ values reach $70 \mathrm{mT}$ and $\mathrm{S}_{-300}$ ratios completely reverse to -1 . $\chi_{\text {ARM }} /$ SIRM ratios remain consistently low. Slightly above the transition to the stratigraphic unit 2 TOC values start to increase and peak in magnetic unit 2 above $10 \%$. The magnetic parameters and ratios clearly reflect the presence of authigenic greigite in this unit (Sandgren \& Snowball 2001).

Magnetic unit 3 (10.40-7.40). The common unifying feature of this complex unit, divided into 5 subunits, is the generally very high $\chi_{\mathrm{ARM}} / \mathrm{SIRM}$ ratios, $\mathrm{S}_{-300}$ ratios practically -1 and a considerable loss of SIRM between the naturally wet and dry samples. Unit 3a can be characterized as transitional units. These parameters all are indicative of the presence of a finegrained magnetite dominated assemblage of stable single domain grains (Maher 1988), which were dissolved as a result of the drying. Unit $3 \mathrm{~b}$ and $3 \mathrm{~d}$ are characterized by peaks in (wet) SIRM values. A slightly finer assemblage here is indicated by peaks in $\mathrm{SIRM} / \chi$ ratios. Unit $3 \mathrm{e}$ shows rapidly changing variations in magnetic concentration parameters. The minor peaks in SIRM values can be correlated to slightly higher $\mathrm{SIRM} / \chi$ values indicating slight grain size variations in the magnetite dominated assemblage. TOC values are fairly consistent between 9 and $10 \%$ in the lower 4 subunits but start to increase from c. $8.30 \mathrm{~m}$.

Magnetic unit 4 (7.40-1.85 m). Magnetic concentrations are very low, lowest in the entire profile. Again there is no or very little difference between wet and dry SIRM values. A gradual influence of a hard magnetic component is reflected in decreasing $\mathrm{S}_{-300}$ ratios. TOC values continue to increase and reach $12 \%$ at $6 \mathrm{~m}$.

Concluding remarks. - The magnetic parameters reflect changes in the environment that also are well correlated to the lithostratigraphy. The magnetic grains in unit 1a are most probably of detrital origin and could thus be considered to represent the natural catchment background values. The decreasing concentrations in unit 1c, coupled to increasing organic carbon content, are assumed to be directly related to decreasing erosion. The peak in TOC in unit 2 is compatible with the formation of greigite (Snowball \& Thompson 1990) and represents a major environmental change. A second significant change takes place at the transition to unit 3. Although the magnetic mineralogy of this unit, dominated of magnetite, appears to be very uniform, the grain size variations as reflected by the $\chi_{\mathrm{ARM}} / \mathrm{SIRM}$ and $\mathrm{SIRM} / \chi$ ratios are not straightforward to interpret. We ascribe however variations in the $\mathrm{SIRM} / \chi$ ratios to water level fluctuations. Relatively finer grains (unit $3 b$ and $3 d$ ) were deposited during phases of rising water level embracing a period of regression (unit 3c).

Pollen stratigraphy. - The pollen diagram from core LB1-98 (Fig. 5A) has been subdivided into 6 local pollen assemblage zones (LPAZ), which are described below.

LB1-1 (12.00-11.45 m). Artemisia-Betula nana-Cyperaceae-Chenopodiaceae LPAZ. Maximum values of Artemisia, Betula nana, Chenopodiaceae and Cyperaceae with high percentages of Pinus sylvestris, and a Picea peak in the top. There are high values of warm-demanding tree taxa like Alnus and Corylus which probably are redeposited. The upper boundary of this
LPAZ is marked by a sharp decrease of herb pollen (Artemisia, Chenopodiaceae and Cyperaceae) and dwarf shrub pollen (B. nana) and by significantly increasing values of Pinus and Polypodiaceae.

LB1-2 (11.45-10.85 m). Pinus-Betula LPAZ. Maximum percentages of Pinus sylvestris among terrestrial pollen (up to $90 \%$ ), fluctuating values of Betula (5-35\%) and marked decline of B. nana, Artemisia and Chenopodiaceae. Polypodiaceae has a distint peak within this zone. Upper boundary is marked by a distinct decrease of Pinus, and increase of Alnus, Ulmus and Corylus followed by a slight increase of Picea and Tilia.

LB1-3 (10.85-9.15 m). Alnus-UlmusCorylus LPAZ. Percentages of Alnus, Ulmus and Corylus pollen increase significantly. Pinus and Betula have rather high values. Quercus and Tilia increase gradually throughout this zone. High values of Poaceae. Upper boundary is indicated by further rise of Picea and Quercus, and slight increase of Fraxinus.

LB1-4 (9.15-7.86 m). Picea-QuercusFraxinus LPAZ. High percentages of Alnus, Betula and Pinus pollen. Increasing values of Picea, with one peak in the middle and another one in the uppermost part, and Quercus pollen. Fraxinus pollen appear for the first time. Significant decreasing percentages of Ulmus pollen. High values of Poaceae. Pediastrum spores slightly increasing upwards. Upper boundary is marked by a Picea peak and a Betula trough, and decreasing values of Corylus.

LB1-5 (7.86-6.30 m). Alnus-Betula-Quercus LPAZ. High percentages of Alnus and Betula. Maximum values of Quercus pollen. Low values of Picea. Decreasing values of Poaceae throughout this zone. Pediastrum spores has very high values. Upper boundary is mainly characterized by increasing values of Picea.

LB1-6 (6.30-5.50 m). Picea-Alnus-Betula LPAZ. High pollen percentages of Picea, Alnus and Betula pollen, decreasing percentages of Ulmus and Quercus pollen. There is a peak of Salix pollen in the middle part of the zone. Pediastrum reach maximum values.

Concluding remarks. - The pollen zonation for LB2-01 (Fig. 5 B) is almost identical with that for LB1-98. However, the LPAZ LB2-1 is less developed and LB2-2 has much higher Poaceae values. The boundary LB2-2/LB2-3 is very sharp 
A Lake Babinskoye, core LB1-98 Pollen and spores

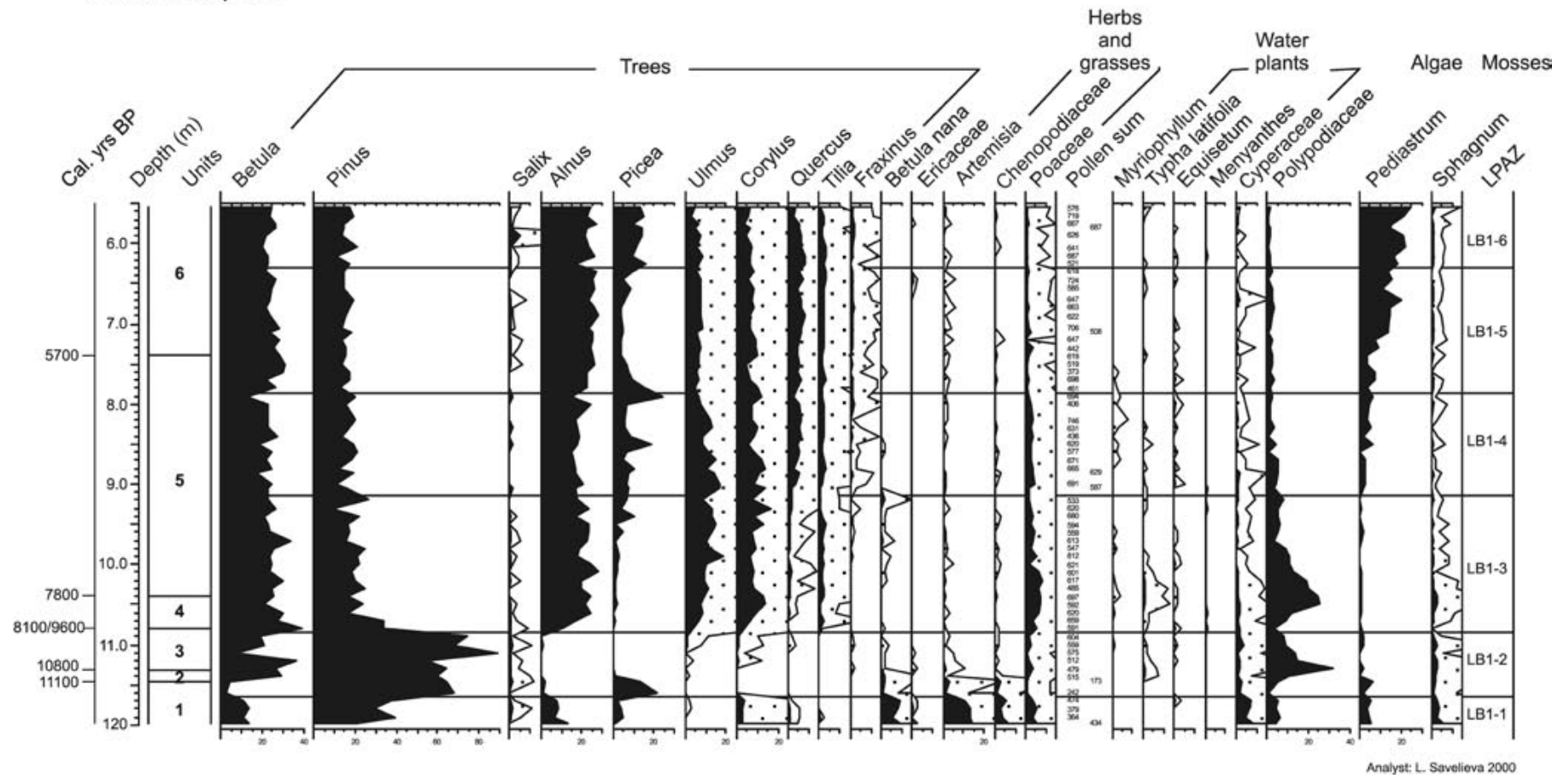

B Lake Babinskoye, core LB2-01
Pollen and spores

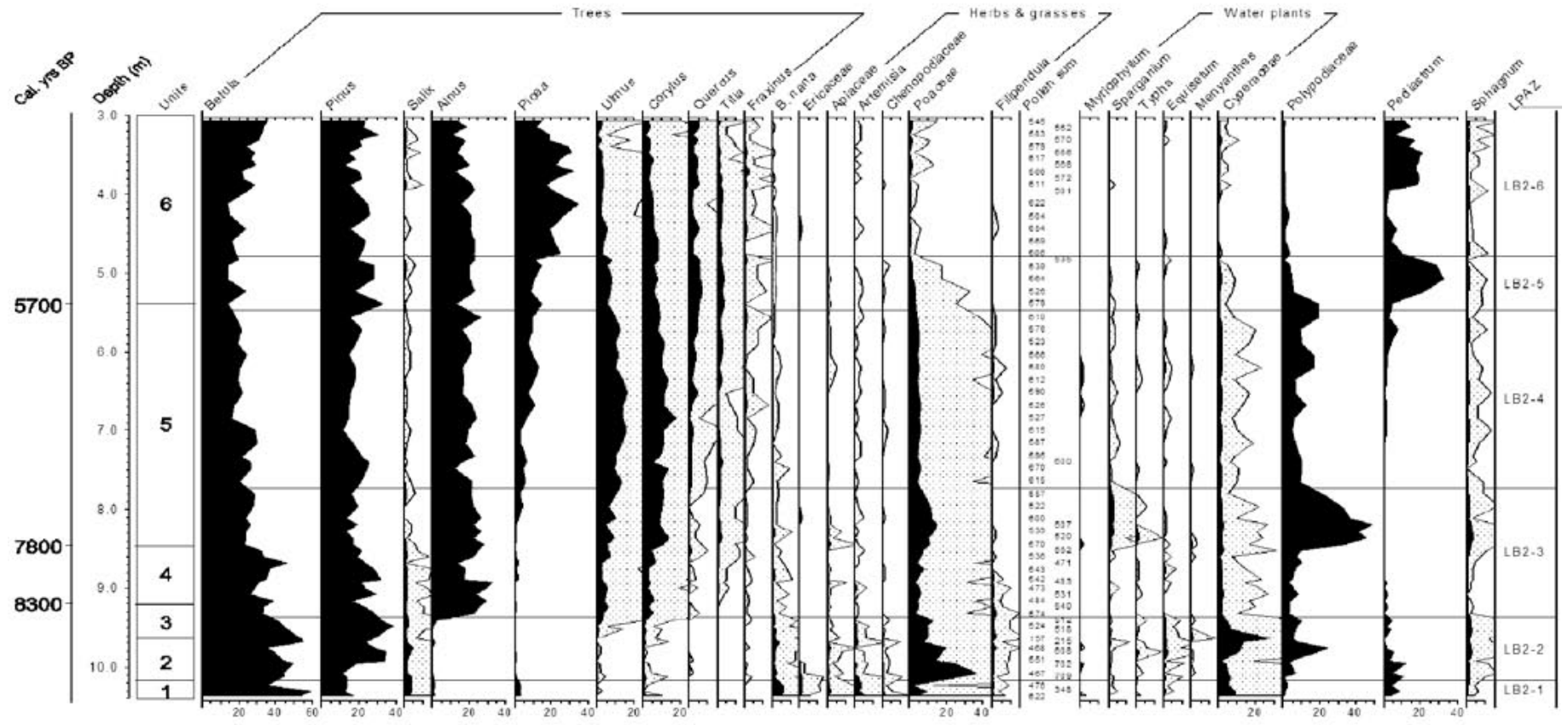

Analyst: L. Savelieva 2001

Fig. 5. A. Pollen diagrams from core LB1. B. Pollen diagrams from core LB2 B. Inferred ages (cal. BP) from Fig. 3. 


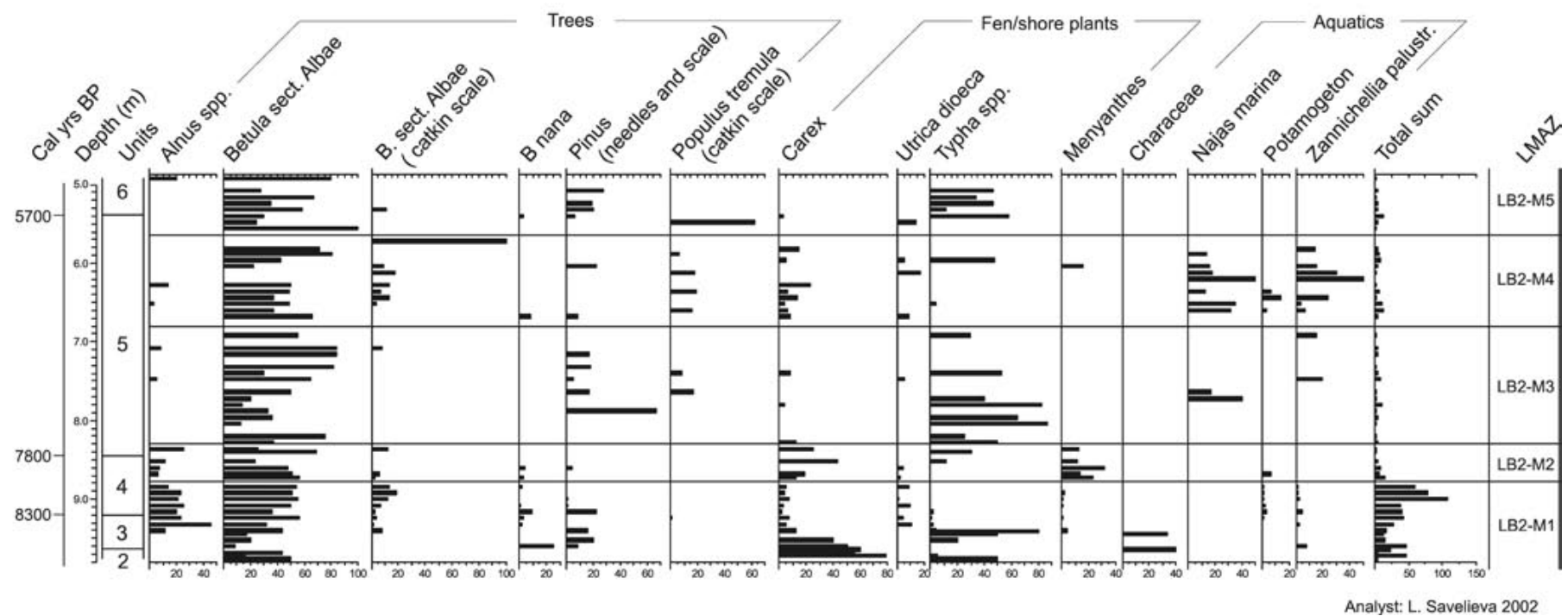

Fig. 6. Plant macrofossil diagram from core LB2.

indicating a hiatus similar to the situation in core LB1-98. This boundary is also at the same level as the sediment boundary $3 / 4$, which evidently represents an important hiatus (see above).

Plant macrofossils. - The near shore core LB2-01 is rather rich in plant macrofossils in contrast to core LB1-98. Based on the analysis it is subdivided into 5 local macrofossil assemblage zones (LMAZ) (Fig. 6).

LB2-M1 (9.80-8.80). Alnus-BetulaCarex-Typha LMAZ. Extremely high values of macrofossils, besides the characterizing taxa also Characeae in the lower part, Potamogeton and Zannichellia in the upper part. Upper boundary is characterized by expansion of Menyanthes.

LB2-M2 (8.80-8.30). Betula-Carex-Menyanthes LMAZ. Alnus, Betula, Carex and Menyanthes are most frequent. Upper boundary characterized by expansion of Typha and decreasing Alnus, Carex and Menyanthes.

LB2-M3 (8.30-6.80). Betula-Typha-Pinus LMAZ. Besides the characterizing taxa Najas marina and Zannichellia palustris occur also. Upper boundary is characterized by an increase of these sea weeds.

LB2-M4 (6.80-5.70). Betula-NajasZannichellia-Carex LMAZ. Very high values of the sea weeds Najas marina, Zannichellia palustris and Potamogeton, indicating more shallow conditions than earlier. Upper boundary characterized by disappearance of these.

LB2-M5 (5.70-5.00). Betula-Pinus-Typha LMAZ. Very few other taxa characterize this zone.

Diatom stratigraphy. - Diatom analysis was performed on core LB2-01. The diagram has been subdivided into 6 local diatom assemblage zones (LDAZ, Fig. 7B).

LB2-D1 (9.98-9.72 m). In this zone the diatom concentration is low. Only 11 diatom species have been found. Mesohaline diatoms represent $63 \%$ of the frustules, $15 \%$ are oligohaline and $22 \%$ are freshwater ones. Oligohaline Rhoicosphenia curvata and Nitschia tryblionella are dominants followed by mesohaline Campylodiscus clypeus. Nearly all diatoms are epiphytic and bottom living. No diatoms were found at $9.78 \mathrm{~m}$ below the water level. According to this data the diatoms were deposited in a shallow, slightly brackish basin.

LB2-D2 (9.72-8.50 m). Low diatom concentration, which gradually increases upwards. Diatom diversity increases in this zone. The freshwater diatoms are the most numerous (96-100\%) ones. Planktonic diatoms prevail in sediments (58-94\%). All dominants are representatives of planktonic: Aulacoseira ambigua, A. granulata. In the lowest sample cold water species A. islandica, A alpigena dominate. This indicates that the diatoms were deposited in a fresh water lake.
LB2-D3 (8.50-7.05 m). The diatom frustule concentration is high but fluctuating. The percentage of mesohaline diatom frustules increases to $45-58 \%$ and oligohaline ones increase to $19 \%$. The most characteristic dominant taxa are the oligohaline planktonic Cyclotella meneghiniana and benthic mesohaline Navicula peregrina and Campylodiscus clypeus. Thalassiosira baltica frustules occur sporadically within this zone. The diatom assemblages are representative of a rather deep water marine bay with relatively high salinity.

LB2-D4 (7.05-6.60 m). The diatom concentration in this zone is rather high. Mesohaline diatom frustules are more than $60 \%$ and increase to $71 \%$ in middle part. Bottom living and epiphytic diatoms prevail (80-99 \% frustules). Mesohaline Campylodiscus clypeus is dominant. Epiphytic oligohaline Epithemia turgida var. westermannii, bottom living Navicula peregrina, Surirella striatula are less numerous in the lower sample. These diatoms dominate in the next two samples with the only difference that the amount of planktonic oligohaline Cyclotella meneghiniana increases in the uppermost sample of the unit. The diatom assemblages indicate salinity as before but lower water level than earlier and later, i.e. interpreted as a regression.

LB2-D5 (6.60-5.46 m). The diatom concentration varies but is still rather high. The dominant groups are mesohaline $(39-55 \%)$ and oligohaline (16-38\%) 
A Lake Babinskoye, core LB1-98

Diatom, selected taxa

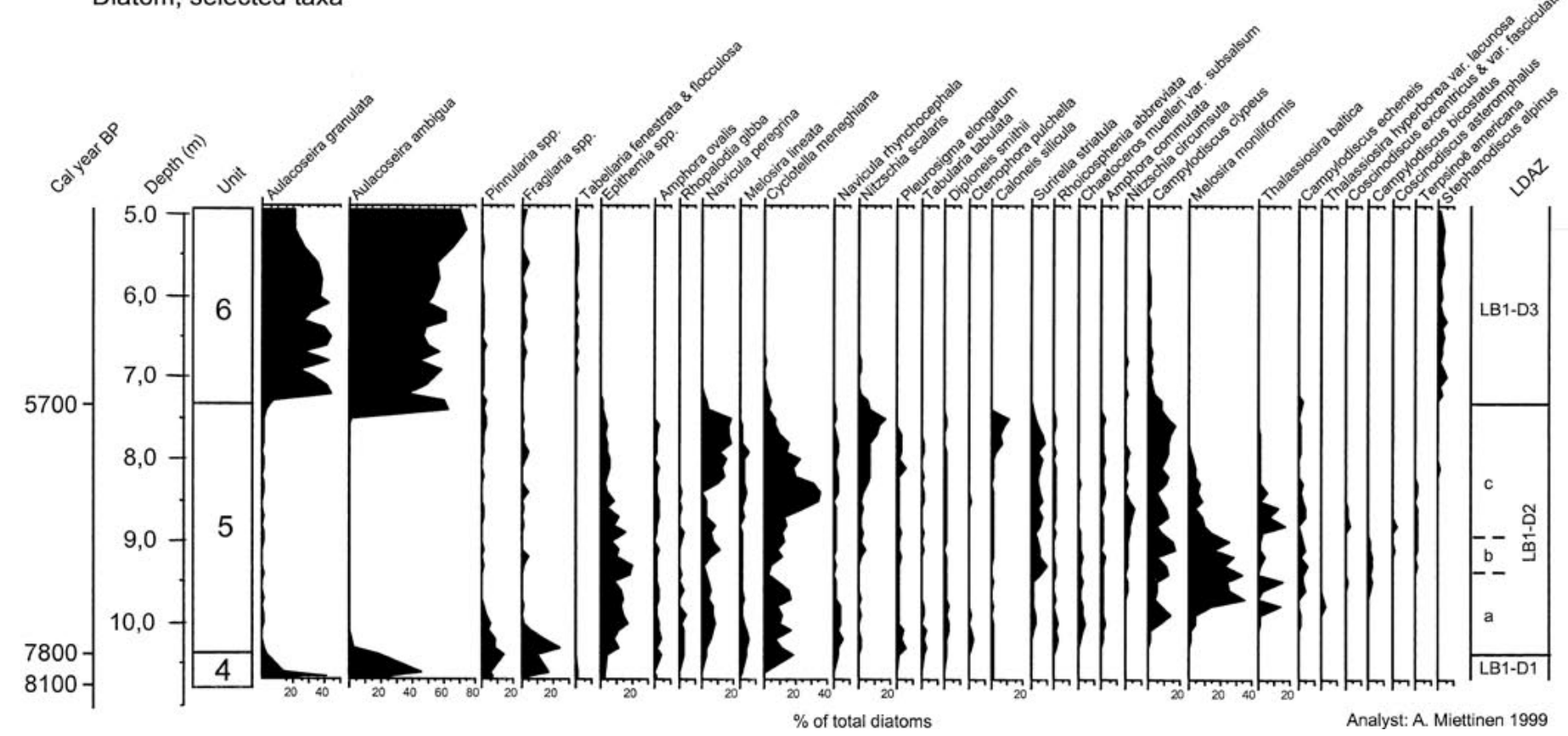

B Lake Babinskoye, core LB2-01

Diatoms, selected taxa

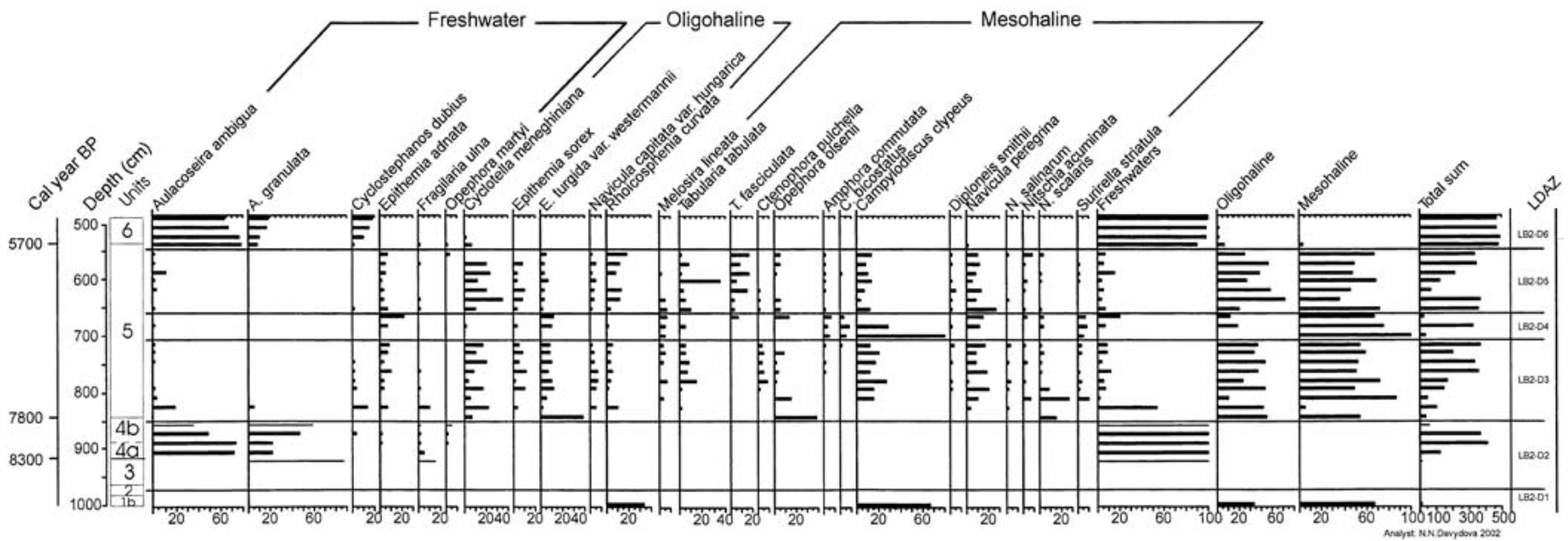

Fig. 7. A. Diatom diagrams from core LB1 (from Miettinen 2002) with LDAZ added. B. Diatom diagrams from core LB2.

diatoms. Cyclotella meneghiniana dominates within the whole zone. There is a large group of subdominant taxa: the oligohaline epiphytic Epithemia turgida var. westermannii, Rhoicosphenia curvata, Tabularia tabulata, T. fasciculata, bottom living Campylodiscus clypeus, Navicula peregrina. The amount of frustules of planktonic diatoms is not more than $39 \%$ . This indicates that the basin was rather shallow with slightly brackish water. However, the sediment infilling means that the water depth was reduced by $\mathrm{c}$.
$2 \mathrm{~m}$ in comparison to the time of LDAZ LB2-D2.

LB2-D6 (5.46-4.90 m). The diatom concentration is very high, planktonic fresh water diatoms dominate in sediments (91-100\% frustules). The most numerous are Aulacoseira ambigua, A. granulata, Cyclostephanos dubius. This indicates a freshwater mesotrophic lake.

Concluding remarks. - The diatom diagram of core LB1-01, produced by Miet- tinen (2002), has been sub-divided into LDAZ to make it comparable with our diagram from core LB2. Based on the reduced values of Thalassiosira baltica around 8.95-9.50 m (Miettinen 2002, fig 43) we think it is justified to separate this interval as a sub-unit (LB1-D2 b). We interpret this subzone a short regression since this species is favoured by large inflow at the sill and deep water. We are correlating LDAZ LB2-D3, D4 and D5 with LB1-D2 a-c. Sub-zone LB1-D2b is correlated with LB2-D4 in the bay which 
has a rich epiphytic flora characteristic for shallow waters. Planktonic mesohaline diatoms are rare in the northern bay in LB but are recorded in LDAZ LB2-D3 supporting that this zone corresponds to the maximum water level in LB.

Environmental reconstruction. - The development of Lake Babinskoye is summarized in the following six stages.

(1) Yoldia Sea stage (before 11000 cal. BP). This period corresponds to the lithostratigraphic unit 1 and magnetic unit $1 \mathrm{a}$ in LB1. LB was connected with the Baltic Sea during the time corresponding to the beginning of the Yoldia Sea, until 11000 cal. BP (Björck 1995, Andrén et al. 2002). The water depth was high and the water fresh to brackish (cf. Heinsalu et al. 2000). The vegetation surrounding the lake was arctic tundra with sparse vegetation, which made the soils susceptible to erosion as reflected by the silty clayey sediments in this unit.

(2) Lake stage 1 (11000-10800 cal. BP). This period corresponds to the lithostratigraphic unit 2 and magnetic unit $1 b$ in LB1. The gradually lower Yoldia Sea caused isolation and a small lake was formed with high organic production. This short period corresponds to the time with the lowest water level of the Yoldia Sea (Andrén et al. 2002). The surrounding terrestrial vegetation was subarctic-boreal birch forest.

(3) Ancylus Lake stage (10800-9600 cal. $\mathrm{BP})$. This period corresponds to the lithostratigraphic unit 3 and magnetic unit 1c in LB1. The basin was re-connected with the Baltic Sea. The diatom flora indicates fresh water conditions with no brackish water influence. The period is correlated with the Ancylus Lake phase (cf. Heinsalu et al. 2000). This is in accordance with recent studies of Ancylus beach ridges in Estonia (Veski 1988). The terrestrial vegetation was characterized by total dominance of pine.

(3/4) Hiatus (9600-8200 cal. BP). There are no sediments from this period, most probably because of erosion caused by strong hydrological changes such as low water level and high storm frequencies particularly around 8200 cal. BP (cf. Berglund et al. 2004). This time span partly corresponds to the Mastogloia Sea stage (Hyvärinen 1991).

(4) Lake stage 2 (8200-7800 cal. BP). This period corresponds to the lithostrati-

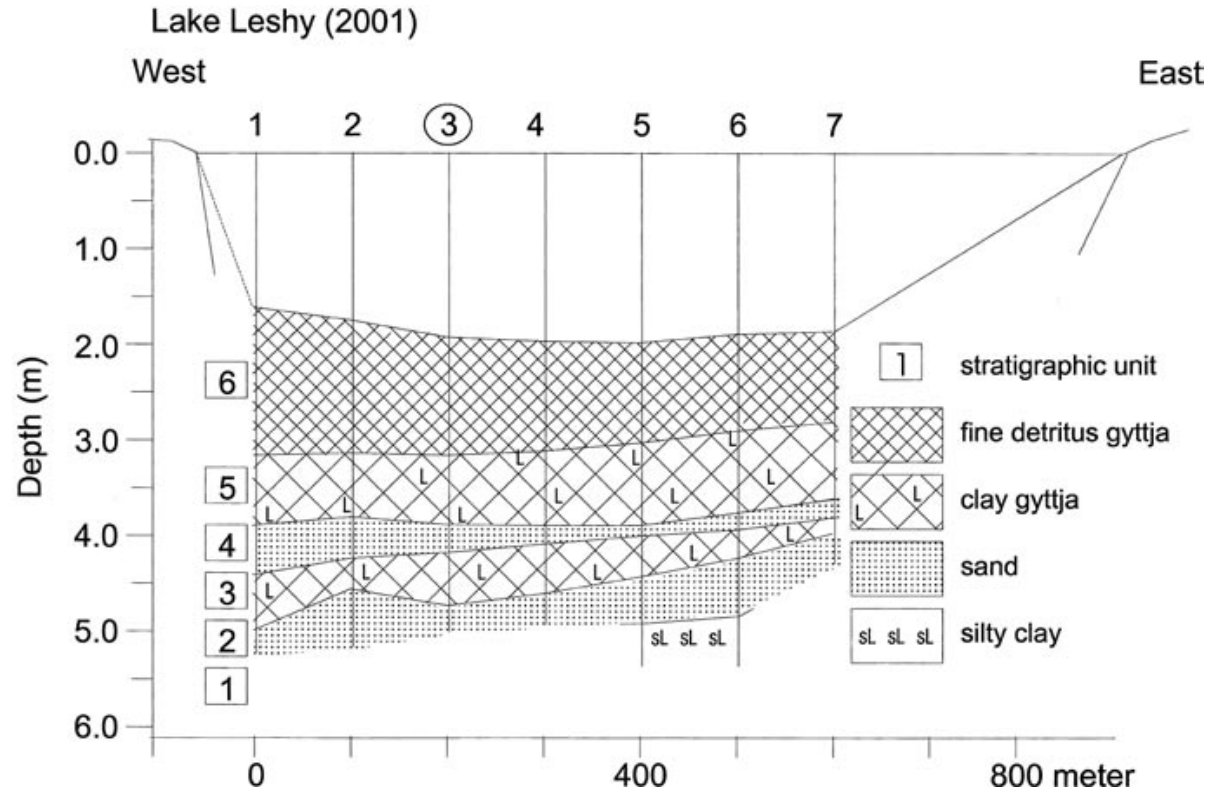

Fig. 8. Stratigraphic transect (corresponding to C-D in Fig. 1C) across Lake Leshy. Stratigraphic units 1-6 according to Table 6 .

graphic unit 4 and magnetic unit 2. LB was a more shallow lake than today which is reflected by more silty and sandy sediments. The diatom flora is representative of a fresh water lake indicating that there was no contact with the brackish Littorina Sea. The terrestrial vegetation was dominated by broad-leaved forests besides pine and birch.

(5) Littorina Sea stage (7800-5700 cal. $\mathrm{BP})$. This period corresponds to the lithostratigraphic unit 5 and magnetic unit $3 \mathrm{a}-$ 3e. The Littorina Sea transgressed into the lake c. $7800 \mathrm{cal}$. BP and transformed the former shallow lake into a rather deep bay. A slight lowering (regression) occurred 7100-6900 cal. BP, as indicated by the mineral magnetic parameters (unit $3 \mathrm{c}$ ) as well as the diatom flora (LDAZ LB1-D2b, LB2-D4). Plant macrofossils as well as the diatom flora indicate that the highest sea-level was reached before $7100 \mathrm{cal}$. BP. The salinity was then about twice that of coastal waters today, approximately 6-8\%o (cf. Westman et al. 1999). After 6100 cal. BP there was a gradual regression until the isolation c. 5700 cal. BP. The terrestrial vegetation was characterized by broad-leaved forests although spruce was expanding throughout the period.

(6) Lake stage 3 (5700 cal. BP to present). This period corresponds to the lithostratigraphic unit 6 and magnetic unit 4. During this final stage the lake was gradually filled in with gyttja and got a mesotrophic character. From c. 5700 cal. BP there was a recession of broad-leaved forest and expanding spruce. Human impact with some deforestation started around 4000 cal. BP, as indicated by expansion of open land vegetation.

Table 6. Sediment description for core LL3-01.

\begin{tabular}{|c|c|c|}
\hline $\begin{array}{r}\text { Depth below } \\
\text { water level }(\mathrm{m})\end{array}$ & Units & Stratigraphic description \\
\hline $0-1.90$ & & Water \\
\hline $1.90-3.17$ & 6 & Dark greenish brown, homogenous fine detritus gyttja \\
\hline $3.17-3.90$ & 5 & $\begin{array}{l}\text { Greenish grey, slightly silty clay gyttja with a } 4 \mathrm{~mm} \text { thick sand layer at } 3.84 \mathrm{~m} \\
\text { and a sandy gyttja layer at } 3.88-3.90 \text {, a piece of wood found at } 3.88 \mathrm{~m}\end{array}$ \\
\hline $3.90-4.32$ & 4 & Grey medium sand with wood pieces at $4.15-4.21$, sharp lower boundary \\
\hline $4.32-4.65$ & 3 & Greenish grey, slightly laminated silty clayey gyttja with a silt layer at $4.42 \mathrm{~m}$ \\
\hline \multirow[t]{2}{*}{$4.65-4.95$} & 2 & Grey silty sand with remains of wood and other plants \\
\hline & 1 & $\begin{array}{l}\text { At coring point } 5 \text { and } 6 \text { the silty sand of unit } 2 \text { was penetrated and a silty clay } \\
\text { was reached at } 4.90 \text { and } 4.77 \text { m respectively (cf. the transect in Fig. } 8 \text { ) }\end{array}$ \\
\hline
\end{tabular}




\section{Lake Leshy, core LL3-01}

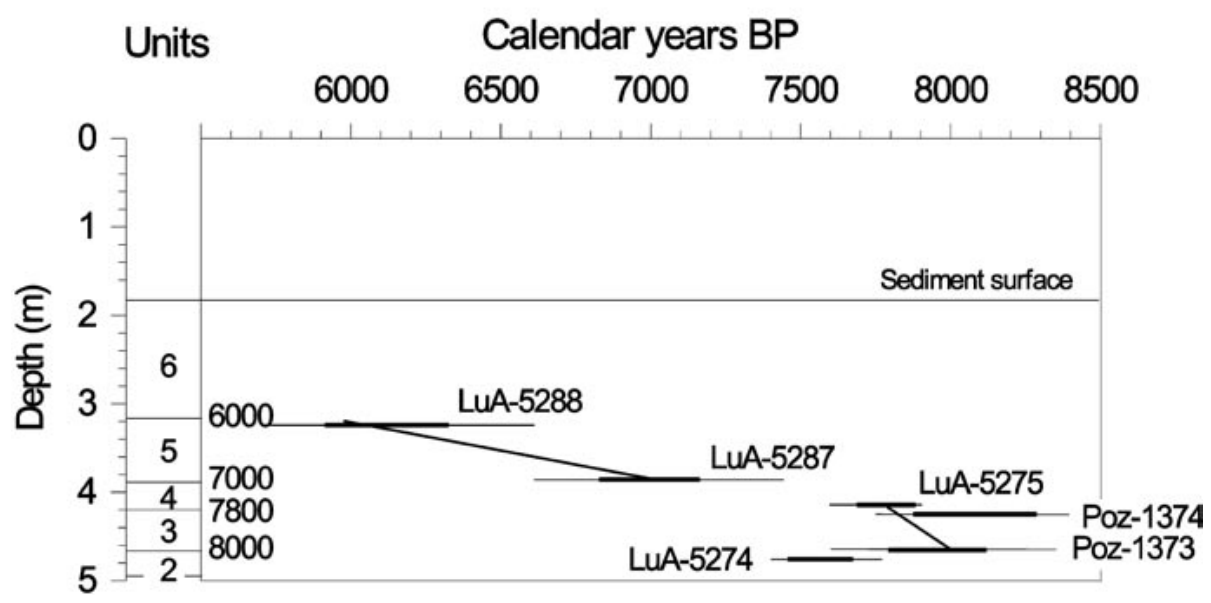

Fig. 9. Time-depth models for core LL3. Inferred ages (cal. BP) of stratigraphic transitions are also shown. Radiocarbon ages are presented in the Appendix.

\section{Lake Leshy (7.6 $m$ a.s.l.)}

Stratigraphy and chronology. - Seven cores were collected along an E-W trending transect (Fig. 8). The stratigraphy is very uniform and all lithostratigraphic units were found with approximately the same thickness across the lake. Core LL301 was chosen for analysis (Table 6). Six dates (Appendix) were obtained from this core and form the base of an age model (Fig. 9). The bottom layer (lithostratigraphic unit 1) is a silty clay probably of late glacial age, overlain by a layer of silty sand (lithostratigraphic unit 2). Above follows two clay-gyttja layers, which are separated by another sand layer (litostratigraphic units 3-5). The lower boundary of the sand (unit 4) is very sharp. The gyttja in units 3 and 5 are interpreted as deposited in relatively deep and calm environment. The sand of unit 4 indicates a high energy environment with rapid deposition. The uppermost unit consists of fine detritus gyttja with a higher organic content than in unit 3 and 5.

The age model (Fig. 9) supports a high deposition rate in the units $2-4$, which also is indicated by generally coarser sediments in contrast to the fine detritus gyttja above. The water-level must have been rather low during deposition of the sand in unit 4 , at least considerably lower than in the underlying silty clayey gyttja. A low water-level represented by the sand is further supported by the erosive unconformity at the unit $3 / 4$ contact. Unstable conditions with active erosion and deposition most probably prevailed during the low-level stand and were to a large extent preventing accumulation. Not until the water level rose again and reached a critical threshold organic sediments could be deposited. This scenario explains the hiatus between unit 4 and 5 . A transgression can be dated to c. $7000 \mathrm{cal}$. BP.

Mineral magnetic analyses. - The more organic lithostratigraphic units (unit 3, 5 , and 6) have low magnetic concentrations in contrast to the practically pure minerogenic units (2 and 4) with higher concentrations (Fig. 10).

Pollen stratigraphy. - The pollen diagram from core LL 3-01 (Fig. 11) has been subdivided into five LPAZ described below. Comparisons are also made with the pollen zones of Lake Babinskoye.

LL3-1 (4.85-4.60 m). Pinus-CorylusUlmus LPAZ. This zone corresponds to the lower part of LPAZ LB1-3.

LL3-2 (4.60-3.93 m). Betula-AlnusUlmus LPAZ. This zone corresponds to the lower part of LPAZ LB1-3. The upper part seems to be missing in Lake Leshy.

LL3-3 (3.93-3.13 m). Pinus-Picea-Corylus LPAZ. This zone corresponds to LPAZ LB1-4.

LL3-4 (3.13-2.70 m). Betula-AlnusQuercus LPAZ. This zone corresponds to LPAZ LB1-5.

LL3-5 (2.70-2.00 m). Pinus-Betula-Picea LPAZ. This zone corresponds to LPAZ LB1-6.

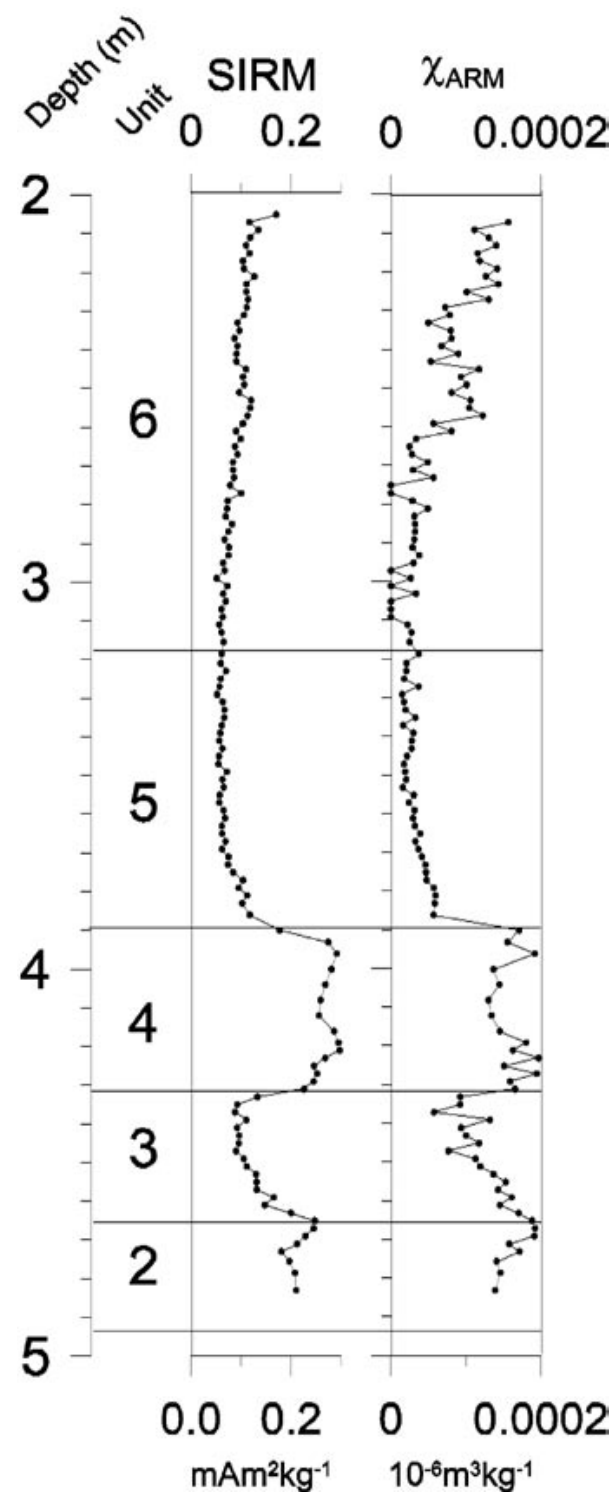

Fig. 10. Selected mineral magnetic parameters of core LL3-01.

The pollen stratigraphy indicates that the basin was quite shallow during the period corresponding to LPAZ LL3-1 and 2, and surrounded by fern rich swamps. Then there was a second rise of the water table during the time corresponding to LPAZ LL3-3 followed by more shallow conditions in connection with isolation from the Littorina Sea. After the isolation the lake was surrounded by swamps and bogs.

Plant macrofossils. - The core LL3-01 was rather poor in plant macrofossils except for wood and bark remains in the sand layer of unit 2. There occurred frequently fruits/seeds of Betula, Alnus, Carex and Typha, and a few Menyanthes 


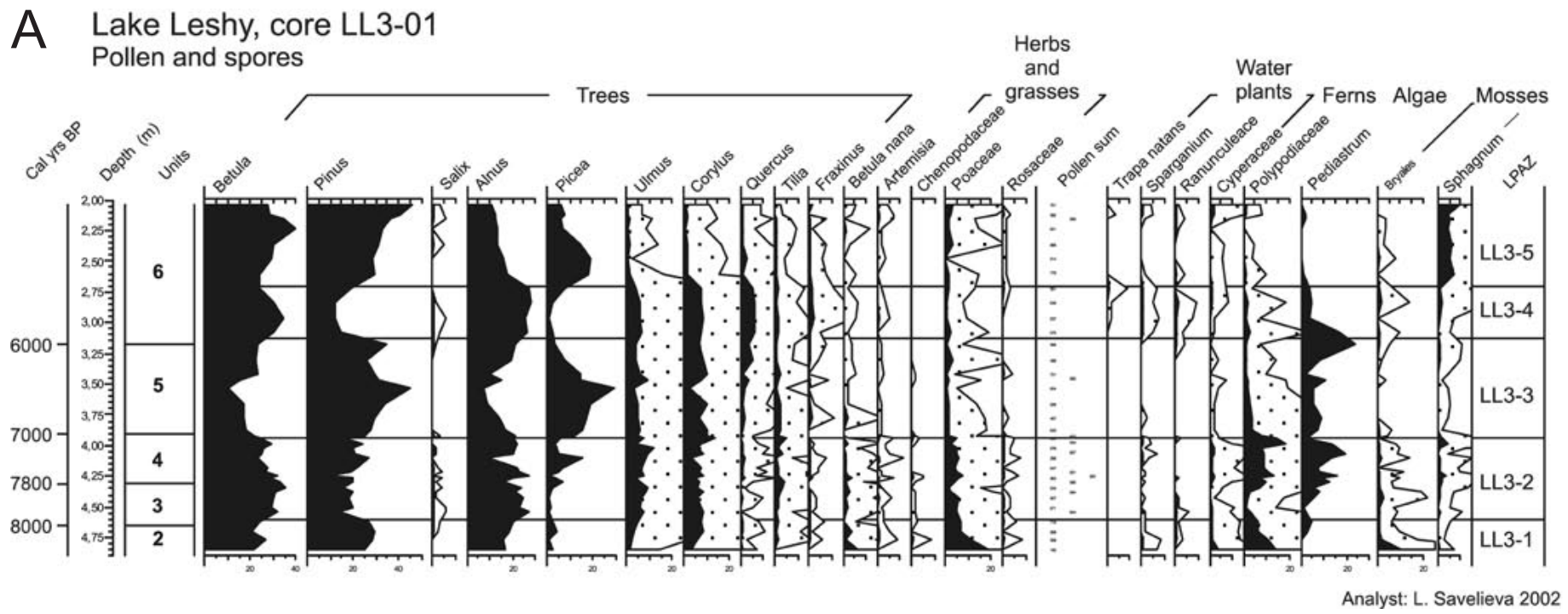

\section{B Lake Leshy, core LL3-01 Diatoms, selected taxa}

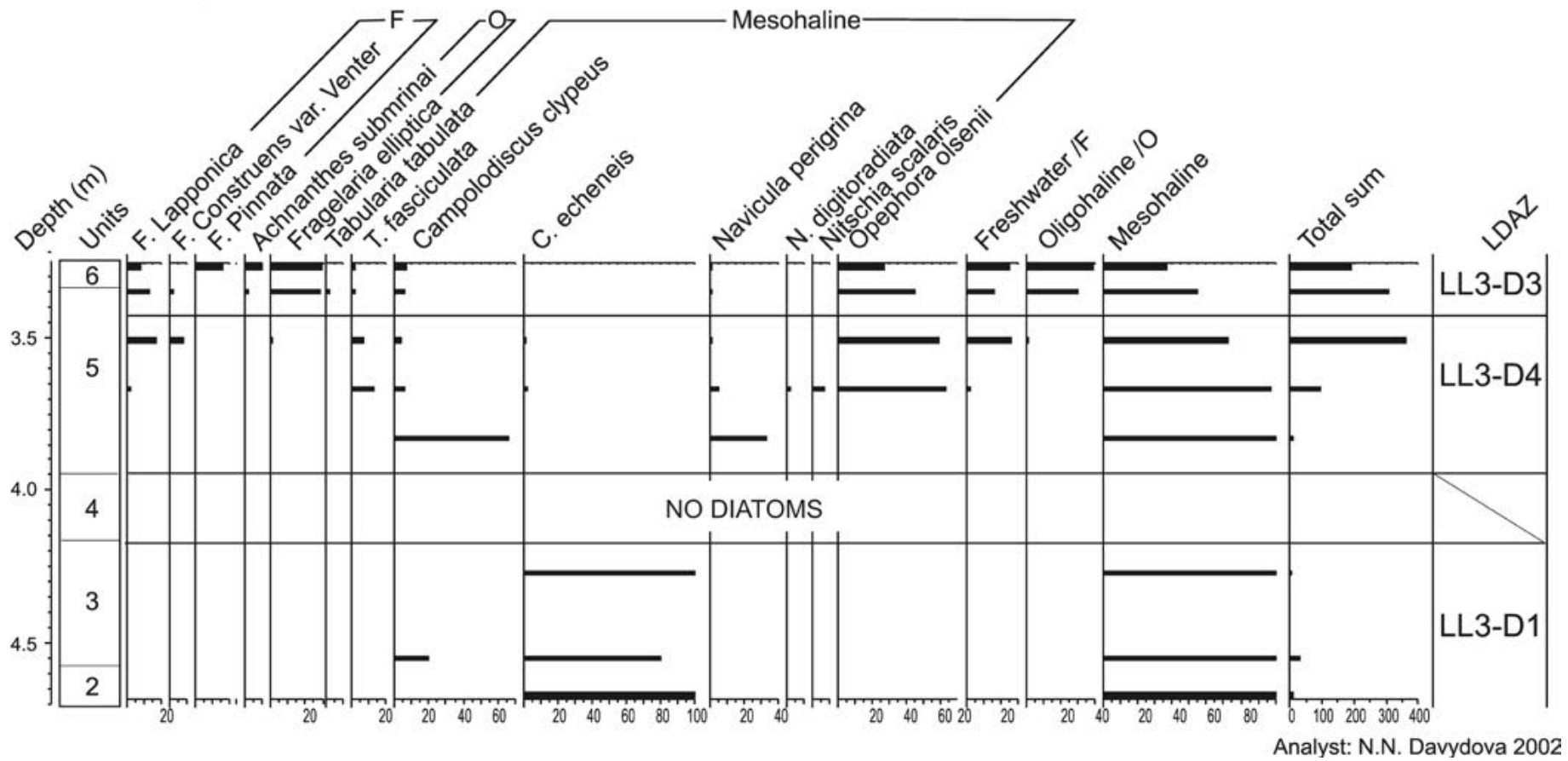

Fig. 11. A. Pollen diagram from core LL3-01. B. Diatom diagram from core LL3-01. Inferred ages (cal. BP) from Fig. 8.

and also Zannichellia palustris. One fruit of Najas marina was found in the gyttja layer of unit 2.

Diatom stratigraphy. - Diatom analysis was restricted to 8 samples from core LL3-01 from the depth interval 4.67-3.27 $\mathrm{m}$ (Fig. 11B). The diatom flora is very poor with dominance of Campylodiscus echineis in unit 3 and Opephora olsenii in unit 5. The basin was shallow and the water brackish during the sedimentation of units 3-5. A richer epiphytic flora in unit 5 possibly indicates lower water level than in unit 3.

Environmental reconstruction. - The development of Lake Leshy is summarized in the following five periods, for the time 8000 to 5000 cal. BP. The sediments reveal no information about the environment during the Early Holocene.
(1) Lake stage 1 (before 8000 cal. BP, corresponding to the lithostratigraphic unit 2) represents a shallow lake, possibly situated in an exposed coastal area. The vegetation was dominated by birch, pine and alder but broad-leaved forests were expanding. Along the shores fern-rich reed vegetation was common.

(2) Littorina stage 1 (8000-7800 cal. BP, corresponding to the lithostratigraphic 
unit 3). The lake was transgressed by the Littorina Sea. The area became an open bay, to some extent sheltered by sandy bars that gradually developed NW of the basin (Fig. 1C). The water was brackish. In the forests on the surrounding hills broad-leaved trees as well as spruce became more common during this time. Ferns were common along the shores.

(3) Littorina stage 2 (7800/7200-7000 cal. BP, corresponding to a hiatus as well as the lithostratigraphic unit 4) represents a regression phase. The sand of unit 4 clearly indicates a high energy environment in comparison to the considerably more organic sediment underneath and above. This conclusion is further supported by the absence of diatoms. With a low water level, probably very close to the lake's bottom, continuous erosion and deposition must have taken place and we accordingly interpret the erosional unconformity in the unit 3/4 contact as caused by a regression that occurred before 7000 cal BP. Organic sediments related to unit 3 were according to this interpretation eroded during this regression.

(4) Littorina stage 3 (7000-6000 cal. BP, corresponding to the lithostratigraphic unit 5). The drastically different character of the overlying sediment in this unit reflects again deposition under more calm conditions which must have occurred in deeper water, i.e. as result of a rising water level. According to the age model the transgression started c. 7000 cal. BP. The sea-level was possibly lower than during Littorina stage 1. The terrestrial vegetation was dominated by pine and spruce but broadleaved trees were also frequent.

(5) Lake stage 2 (6000 cal. BP onwards corresponding to lithostratigraphic unit 6). When the basin became isolated around

\section{Lake Glubokoye, core LG1-03}

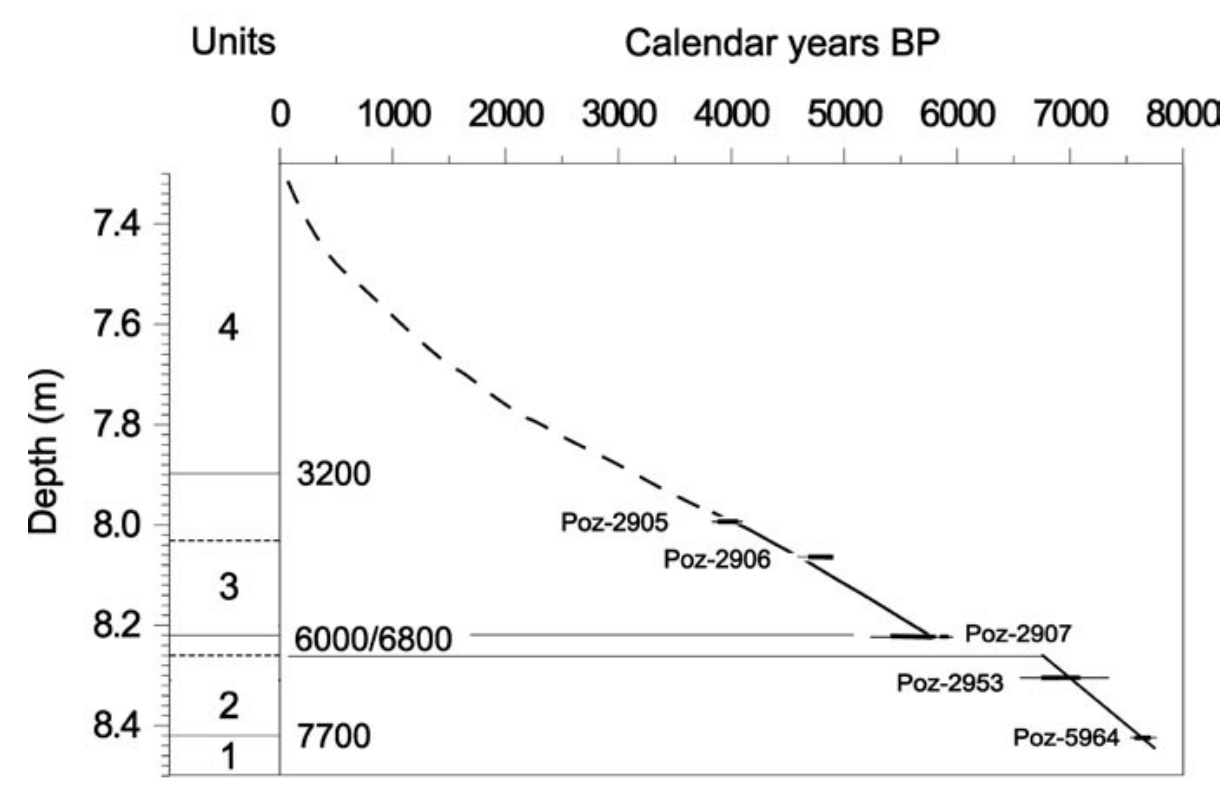

Fig. 12. Time depth model for LG1-03 Inferred ages (cal. BP) of stratigraphic transitions are also shown. Radiocarbon ages are presented in the Appendix.

6000 cal. BP a shallow lake with slow sedimentation developed. The vegetation around the lake changed towards a complete dominance of birch, pine and spruce, with alder swamps and bogs surrounding the lake.

\section{Lake Khabalovskoye (6.7 $m$ a.s.l.)}

In 1998 as well as in 2003 a coring was made in the central part of this very shallow lake (Fig. 1C). The stratigraphy, based on the description in the field, is presented in Table 7. The lithostratigraphic unit 1 is

Table 7. Sediment description for core LK1-03.

\begin{tabular}{rrl}
\hline $\begin{array}{r}\text { Depth below } \\
\text { water level }(\mathrm{m})\end{array}$ & Units & Stratigraphic description \\
\hline $0-1.20$ & & Water \\
$1.20-2.45$ & 3 & $\begin{array}{l}\text { Grey, sandy laminated silt } \\
\text { Brown moss-sedge peat with Phragmites stems frequently between 2.84-2.92, } \\
\text { Menyanthes seeds also frequent }\end{array}$ \\
$3.35-3.45+$ & 2 & \begin{tabular}{l} 
Grey, silty clay \\
\hline
\end{tabular}
\end{tabular}

Table 8. Sediment description for core LG1-03.

\begin{tabular}{rrl}
\hline $\begin{array}{r}\text { Depth below } \\
\text { water level }(\mathrm{m})\end{array}$ & Units & Stratigraphic description \\
\hline $0-7.30$ & & Water \\
$7.30-7.90$ & 4 & Dark green fine detritus gyttja. \\
$7.90-8.22$ & 3 & Dark green, slightly silty fine detritus gyttja. Transitional layer 7.90-8.03 \\
$8.22-8.43$ & 2 & Very dark green, silty fine detritus gyttja. Transitional layer 8.22-8.26 \\
$8.43-8.50$ & 1 & Light grey clay, upper boundary distinct \\
\hline
\end{tabular}

interpreted as Baltic Ice Lake clay. Probably there is a hiatus between units 1 and 2 corresponding to Early Holocene. The moss-sedge peat (lithostratigraphic unit 2), has been deposited in a fen at 4-5 m a.s.l. without any impact from the sea. The sea level was then lower than c. $4 \mathrm{~m}$. This phase is dated to $8400-7800 \mathrm{cal}$. BP (Appendix). This embogging reflects a rise of the ground water table probably caused by a sea level rise named "Littorina 1 " in Blekinge (Berglund et al. 2004). The peat is overlain by sandy silt (lithostratigraphic unit 3), interpreted as a transgression sediment deposited in a wide sound between the Kurovitsky and the Soikino plateaus (Fig. 1C), probably in the beginning of the Littorina transgression when the sea-level reached above the sill at ca. $7 \mathrm{~m}$ a.s.l.

\section{Lake Glubokoye (9.2 $m$ a.s.l.)}

This lake is situated in the uppermost part of the Kyamishi river system (Fig. 1C). The lake was visited in 2003 in order to document whether the Littorina transgression also reached this lake. Because of too deep water a core could only be collected from a shallower bay in the NW (Table 8). The Holocene sequence is only 1.13 $\mathrm{m}$, partly ascribed to a hiatus during the Early Holocene (between units 1 and 2) 


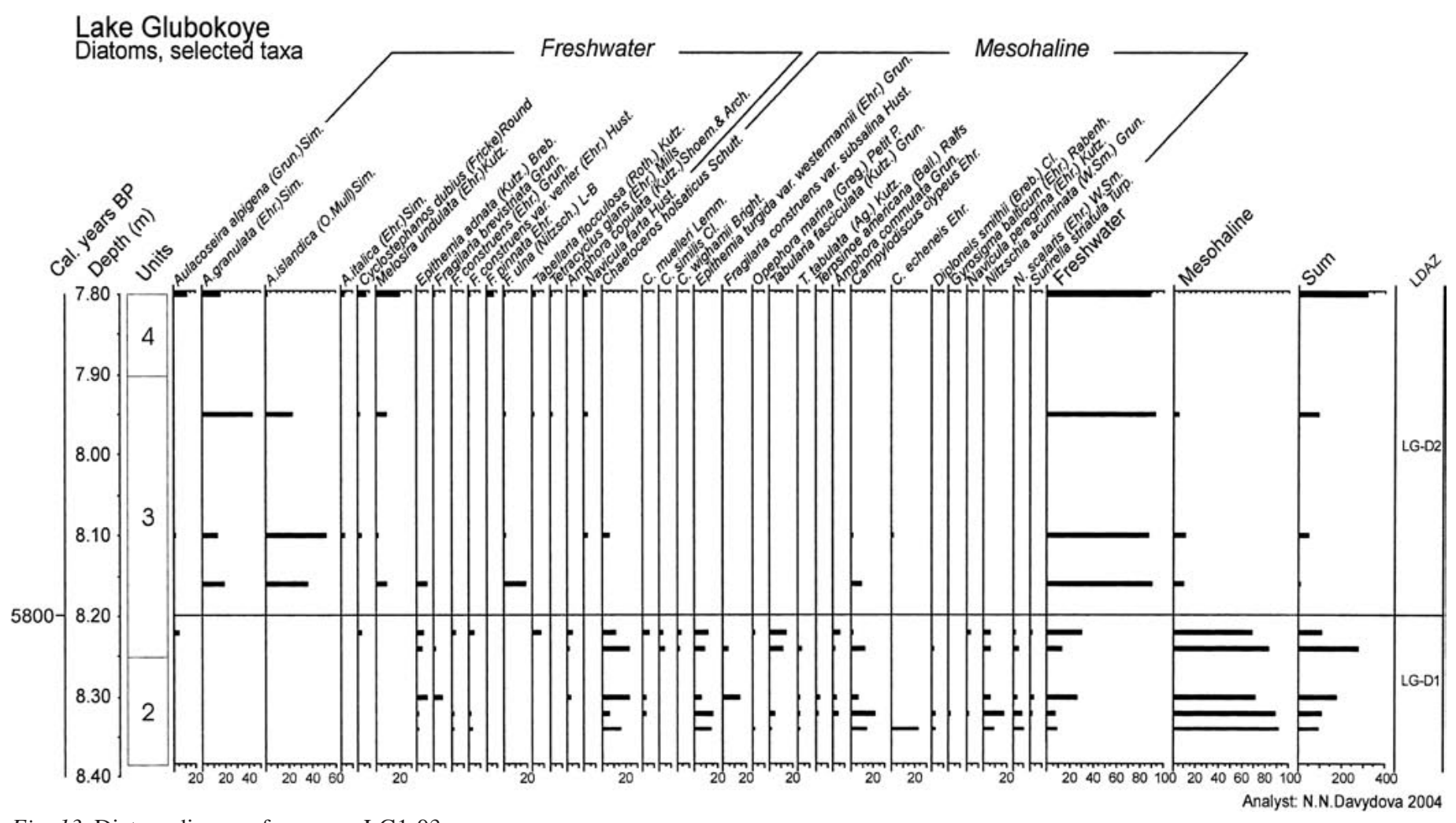

Fig. 13. Diatom diagram from core LG1-03.

and partly caused by the oligotrophic character of the lake during the Holocene. In addition the age model (Fig. 12) also indicates a hiatus between units 2 and 3 , which corresponds to the transition layer between 8.22 and 8.26 (Table. 8). With this interpretation unit $2(8.43-8.26)$, a sandy fine detritus gyttja, is dated to c. 7700 to $6800 \mathrm{cal}$. BP (Fig. 12). Diatom analyses (Fig. 13) confirm that this unit was deposited in a brackish environment. LDAZ LG-D1 is characterized by high content of mesohaline diatoms (Campylodiscus clypeus, Chaetoceros holsaticus, Epithemia turgida var. westermannii, Nitzschia acuminata, N. scalaris). This indicates that the Littorina Sea actually transgressed into this basin during the same time period as the first transgression in Lake Babinskoye and reached above 10 $\mathrm{m}$. The hiatus at c. 6900-6000 cal. BP was possibly caused by unstable sedimentation conditions. Unit 3 , which is a silty fine detritus gyttja, is dated to c. 6000-3200 cal. BP. The diatom analysis indicates that this unit is of limnic origin with higher productivity. LDAZ LG-D2 is dominated by freshwater diatoms (Melosira undulata and Aulacoseira granulata). We interpret the coarser grain size of this unit as a result of an internal hydrological change of the isolated lake from a higher to a lower water level, an environmental change identified in many lake basins of NW Europe (cf. Digerfeldt 1988). The sediment sequence is terminated by a more organic rich fine detritus gyttja (lithostratigraphic unit 4), deposited between $3200 \mathrm{cal}$. BP and the present.

\section{Discussion}

When comparing the pattern of the Littorina transgression around the Gulf of Finland it is obvious that in recent studies only one main transgression has been documented along the northern coast of the Gulf. This applies to the Helsinki area with transgression maximum at $\mathrm{c}$. $30 \mathrm{~m}$ a.s.l. (Eronen 1974; Hyvärinen 1999) as well as to the Virolathi area in southeastern Finland with maximum at c. $25 \mathrm{~m}$ (Miettinen 2002) and the Karelian Isthmus in Russia with maximum at c. $10 \mathrm{~m}$ (Miettinen 2002). On the southern coast of the Gulf four minor transgressions, reaching c. $25 \mathrm{~m}$, were identified in the Tallinn area, Estonia (Kessel \& Raukas 1979). However, the stratigraphical and chronological records from these sites have not been considered convincing and the interpretation has therefore been revised (Raukas 1991). Further east, in the Narva area, stratigraphical studies have recently revealed three minor Littorina transgressions with maximum at c. 10 m a.s.l. (Lepland et al. 1996). Our study in the Ingermanland area slightly NE of Narva indicates two minor transgressions between 7800 and $5700 \mathrm{cal}$. BP. The maximum transgression at c. $10 \mathrm{~m}$ a.s.l. has been dated to c. 7600-7200 cal. BP (Fig. 14). The main reasons why minor transgression waves have been detected here seems to be a combination of the following factors: 1 . low isostasy not overriding eustatic variations, 2. topography and morphology with the fjord like character of the landscape including basins at different elevations 3 . Our methodological approach by investigating several ancient lagoons at different altitudes.

When comparing areas along or below the $10 \mathrm{~m}$ Littorina isobase one would expect that minor transgressions had occurred also on the Karelian Isthmus near St. Petersburg. This is also indicated in several old studies (see Introduction), but they have not been confirmed by recent investigations by Miettinen (2002). Further south, in Lithuania, the transgression reached c. $5 \mathrm{~m}$ a.s.l. In the Sventoji area stratigraphical studies have revealed 
three minor transgressions between 8000 and 5500 cal. BP (Kabaliene \& Rimantiene 1995). On the western side of the Baltic Sea old studies on the island of Öland, situated slightly north of the $10 \mathrm{~m}$ isobase, a double transgression reaching c. $10 \mathrm{~m}$ a.s.l. has been documented (Lundqvist 1928).

Our intense studies along the Blekinge coast, where the $10 \mathrm{~m}$ Littorina isobase is running parallel with the south coast, 5 to 6 minor transgressions have been identified between 8500 and 3000 cal. BP (Fig. 14). The two highest, L2 and L3 are dated to 7800-6900 and 6400-5600 cal. $\mathrm{BP}$ respectively (Yu 2003b). These are within the chronological errors almost synchronous with the two transgressions identified in the present study. The maximum level was reached during L3, at c. $8 \mathrm{~m}$ a.s.l., i.e. slightly later than in Ingermanland because of lower isostasy. Corresponding transgressions are also identified along the Öresund coast (Digerfeldt 1975; Christensen 1995). On the Great Belt coast of Själland similar transgression patterns have been documented but the transgression maximum, 1-3 $\mathrm{m}$ a.s.l., is younger, 5500-5000 cal. BP (Christensen 2001; Hede 2003).

The synchroneity for the minor transgressions along the Littorina isobases supports the theory that the sea-level fluctuations in the southern Baltic Sea are caused mainly by global ice-volume-equivalent changes combined with sub-millennialscale variations of regional atmospheric pressure conditions ( $\mathrm{Yu}$ 2003a, 2003b). Stratigraphic studies of lagoonal sediments in Blekinge indicate sedimentation conditions which are explained by higher storm frequency during the transgression phases (Yu 2003a). Changes in solar radiation may influence the North Atlantic atmosphere pressure conditions (NAO) that has an impact on the regional storminess and the sea-level in the Baltic Sea (Yu 2003b, cf. Andersson 2002). Our data from Ingermanland does not contradict this hypothesis.

\section{Conclusions}

- The lake system in the coastal lowland of Ingermanland was transgressed by the Littorina Sea between 8000 and 5700 cal. BP. The salinity of the coastal waters is estimated to $6-8 \%$ which is about twice that of today.

- Two minor transgression waves have been identified in this area, dated to 7800

\section{Holocene shore displacement in Ingermanland, NW Russia}

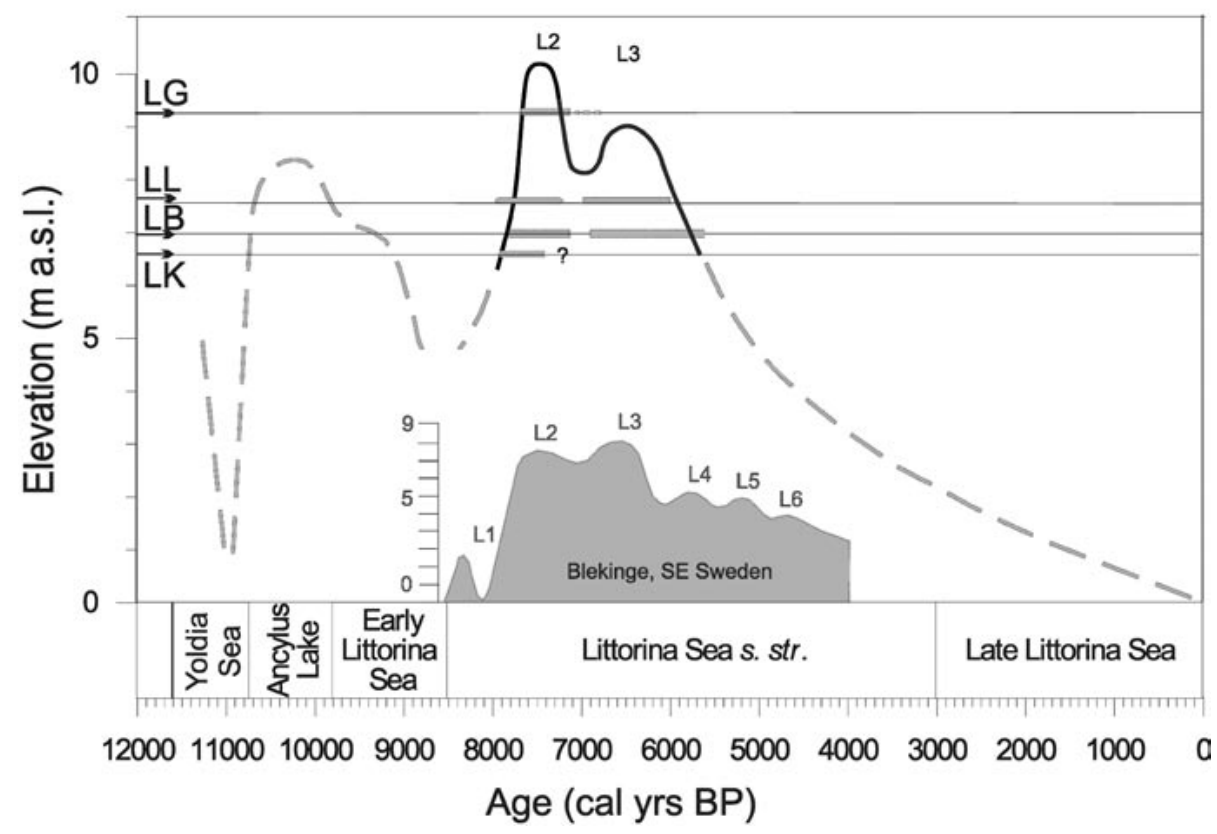

Fig. 14. Synthesis of Holocene shore displacement in our study area in Ingermanland where the curve represents the average sea level of the Gulf of Finland. For each lake basin recorded transgression/s are indicated with a horizontal grey bar. The development for early and late Holocene is tentative and shown with a broken line. The Littorina Sea transgression curve for the Blekinge area (Berglund et al. 2004) is shown for comparison.

7100 and 6900-6000 cal. BP, respectively. The peak of the Littorina sea-level, c. $10 \mathrm{~m}$ a.s.l., was reached during the first of these, and is dated to 7600 to $7200 \mathrm{cal}$. BP.

- The transgression maximum at c. $10 \mathrm{~m}$ a.s.l. confirms the $10-\mathrm{m}$ isobase reconstructions made by Markov (1931) and Miettinen (2002).

- The two minor transgressions are synchronous with corresponding transgressions recorded along the $10 \mathrm{~m}$ Littorina isobase from Ingermanland across Blekinge to Själland.

- In areas with low isostatic uplift since mid-Holocene, minor transgressions have occurred probably during the entire Littorina transgression/regression time, i.e. 8500-3000 cal. BP.

- Minor sealevel changes recorded in southern Baltic Sea are caused by a combination of global and regional climate changes.
Acknowledgements. - Financial support for this investigation from the Royal Swedish Academy of Sciences (KVA) and the Swedish Institute (SI) is acknowledged. Discussions with Svante Björck and Kurt Lambeck have contributed to valuable improvements of the paper for which we are very grateful. Hannu Hyvärinen and Arto Miettinen have generously provided the raw diatom data from Lake Babinskoye core LB1. Göran Skog performed the calibration of the radioca diocarbon dates. We also would like to thank our colleague Lena Barnekow, Denis Kuznetsov, Arto Miettinen and Shiyong Yu as well as our excellent driver Vladimir Zinchenko for help and support during our field campaigns in Ingermanland. The paper was reviewed by Wolfram Lemke and Thomas Andrén and we are greatful to them both. Especially we express our thanks to Andrén for his most constructive criticism which lead to significant improvements of the manuscript.

\section{References}

Ailio, J., 1915: Die geographische Entwicklung des Ladogasees in postglazialer Zeit. Fennia 38:3. $157 \mathrm{pp}$.

Andersson, H.C., 2002: Influence of long-term regional and large-scale atmospheric circulation on the Baltic sea level. Tellus Series A 54, 76-88.

Andrén, T., Lindeberg, G. \& Andrén, E., 2002: Evidence of final drainage of the Baltic Ice Lake and the brackish phase of the Yoldia Sea in glacial varves from the Baltic Sea. Boreas 31, 226-238.

Battarbee, R.W., 1986: Diatom analysis. In B.E. Berglund (ed.): Handbook of Holocene Palaeoecology and Palaeohydrology, 527-570. John Wiley \& Sons. 
Berghell, H., 1896: Bidrag till kännedomen om södra Finlands kvartära nivåförändringar. Bulletin de la Commission Géologique de Finlande 5.64 pp.

Berglund, B.E., 1964: The post-glacial shore displacement in eastern Blekinge, southeastern Sweden. Sveriges Geologiska Undersökning C 599. $47 \mathrm{pp}$.

Berglund, B.E., 1971: Littorina transgressions in Blekinge, south Sweden. A preliminary report. Geologiska Föreningens i Stockholm Förhandlingar 93, 625-652.

Berglund, B.E. \& Ralska-Jasiewiczowa, M., 1986: Pollen analysis and pollen diagrams. In B.E. Berglund, (ed.): Handbook of Holocene palaeoecology and palaeohydrology, 455-484. John Wiley $\&$ Sons, Chichester.

Berglund, B.E., Sandgren, P., Barnekow, L., Hannon, G., Jiang, H. Skog, G. \& Yu, S.-Y., 2004: Early Holocene history of the Baltic Sea, as reflected in coastal sediments in Blekinge, southeastern Sweden. Quaternary International (in press).

Björck, S., 1995: A review of the history of the Baltic Sea, 13.0-8.0 ka BP. Quaternary International 27, $19-40$.

Christensen, C., 1995: The Littorina transgressions in Denmark. In A. Fischer, (ed.): Man and sea - coastal settlement above and below present sealevel, 15-22. Oxford: Oxbow Books.

Christensen, C., 2001: Kystbosaettelse og havniveauaendringer i stenaldern. In O.L. Jensen, S.A. Sörensen, \& K.M. Hansen, (eds): Danmarks jaegerstenalder - status og perspektiver, 183193. Hörsholms Egns Museum.

Davydova N.N., 1985: Diatomovye vodorosli - indikatory ecologicheskikh uslovii v golotsene. [Diatom algae as indicators of ecological situations during the Holocene]. Leningrad. $243 \mathrm{pp}$. [in Russian].

De Geer, G., 1894: Om kvartära nivåförändringar vid Finska viken. Geologiska Föreningens $i$ Stockholm Förhandlingar 16, 639-655.

Digerfeldt, G., 1975: A standard profile for Littorina transgressions in western Skåne, South Sweden. Boreas 4, 125-142.

Digerfeldt, G., 1988: Reconstruction and regional correlation of Holocene lake-level fluctuations in Lake Bysjön, South Sweden. Boreas 17, 165182.

Dolukhanov, P.M., 1979: The Quaternary history of the Baltic. Leningrad and Soviet Carelia. In V. Gudelis, \& L.-K. Königsson (eds.): The Quaternary History of the Baltic, 115-125. Acta Universitatis Upsaliensis. Symposia Universiatis Upsaliensis Annum Quingentesimum Celebrantis 1. Uppsala.

Eronen, M., 1974: The history of the Littorina Sea and associated Holocene events. Commentationes Physico-Mathematicae, Societas Scientarum Fennicae 44, 79-195.

Eronen, M., 1988: A scrutiny of the Late Quaternary history of the Baltic Sea. Geological Survey of Finland. Special Paper 6. 11-18.

Grimm, E., 1987: Coniss: a FORTRAN 77 program for stratigraphical constrained cluster analysis by the method of incremental sum of squares. Computers and Geosciences 13, 13-37.

Grimm, E., 1991: Tilia 1.12, Tilia*Graph 1.18. Illinois State Museum, Research and Collection Center. Springfield, Illinois.

Hede, S.U., 2003: Prehistoric settlements and Holocene relative sea-level changes in northwest Sjaelland, Denmark. Bulletin of the Geological Society of Denmark 50, 141-149.

Heinsalu, A., Kohonen, T. \& Winterhalter, B. 2000: Early post-glacial environmental changes in the western Gulf of Finland based on diatom and lithostratigraphy of sediment core B-51. Baltica $13,51-60$.

Hustedt, F., 1930: Die Süsswasser Flora Mitteleuropas 10 . Jena. $466 \mathrm{pp}$.

Hyvärinen, H., 1999: Shore displacement and Stone Age dwelling sites near Helsinki, southern coast of Finland. In M. Huurre (ed.): Dig it all-papers dedicated to Ari Siiriäinen, 79-89. The Finnish Antiquarian Society, The Archaeological Society of Finland. Helsinki.

Hyvärinen, H., 1991: Variations du niveau relatif de la mer dans la région Baltique durant les temps tardiglaciaires et Holocènes. L'Anthropologie 95, 729-742.

Hyyppä, E., 1932: Die postglazialen Niveauverschiebungen auf der Karelischen Landenge. Fennia $56.241 \mathrm{pp}$.

Hyyppä, E., 1937: Post-Glacial changes of shoreline in south Finland. Bulletin de la Commission Géologique de Finlande 120. $225 \mathrm{pp}$.

Kabaliene, M. \& Rimantiene, R., 1995: Holocene changes in the palaeoecological conditions of the Lithuanian coast around Sventoji settlement. In A.-M. Robertsson, S. Hicks, Å. Åkerlund, J. Risberg, \& T. Hackens (eds): Landscapes and Life, Studies in Honour of Urve Miller. PACT 50, 185-196.

Kessel, H. \& Raukas, A., 1979: The Quaternary history of the Baltic Estonia. In V. Gudelis, \& L.-K. Königsson (eds): The Quaternary history of the Baltic, 127-146. Acta Universitatis Upsaliensis.

Kleymenova, G.I., Vishnevskaya, E.M., Dolukhanov, P.M. \& Latysheva, N.M.,1988: K paleogeographii severo-vostochnogo poberezhiya Finskogo zaliva $\mathrm{v}$ srednev i pozdnem golotsene [To paleogeography of the NE coast zone of the Gulf of Finland in the Middle and the Late Holocene]. Izvestiya of the Russian Geographical Society 120, 302-314. [In Russian].

Krammer, K. \& Lange-Bertalot, H., 1986-1991: Bacillariophyceae. In H. Ettl, J. Gerloff, H. Heyning, \& D. Mollenhauer (eds.): Süsswasserflora Mitteleuropas 2/1-4. G.Fisher, Stuttgart.

Kupriyanova, L.A. \& Alyoshina, L.A., 1972: Pyltsa i spory rastenii flory Evropeiskoi chasti SSSR [Pollen and spores of plants from the Flora of European Part of the USSR]. Nauka, Leningrad, 1-171. [In Russian.]

Lepland, A., Hang, T., Kihno, K., Sakson, M., Sandgren, P. \& Lepland, A., 1996: Holocene sea-level changes and environmental history in the Narva area, north-eastern Estonia. In T. Hackens, S. Hicks, V. Lang, U. Miller \& L. Saarse (eds.): Coastal Estonia. PACT 51, 313-358.

Liljegren, R., 1982: Palaeoecology and shore displacement in a Littorina bay at Spjälkö, Blekinge. LUNDQUA Thesis 11, Lund University, Lund, Sweden. $95 \mathrm{pp}$.

Lundqvist, G., 1928: Studier i Ölands myrmarker. Sveriges Geologiska Undersökning C 353. 183 pp.

Maher, B.A., 1988: Magnetic properties of some synthetic sub-micron magnetites. Geophysical Journal of the Royal Astronomical Society 94, 83-96.

Malakhovsky, D.B. \& Markov, K.K., 1969: Geomorphologiya i tsctvertichnye otlozheniya severozapada evropeiskoi chasti SSSR (Leningradskaya, Pskovskaya i Novgorodskava oblasti) [Geomorphology and Quaternary deposits of the NorthWest of the European part of USSR (Leningrad, Pskov and Novgorod Regions)]. Leningrad, Nauka. 256 pp. [in Russian].

Malakhovsky, D.B., Gey, N.A., Dzhinoridze, R.N., Arslanov, Kh.A., 1989: K paleogeographii golotsena raiona Leningrada (razrez u Nevskogo lesoparka [To paleogeography of the Holocene of the Leningrad region (outcrop near the Nevsky forest park)]. Vestnik Leningradskogo Gosudarstvennogo Universiteta Ser. 7, 1(7), 92-98. [in Russian].

Markov, K.K., 1931: Region Razvitie reliefa severozapadnoi chasti Leningradskoi oblasti [Development of the relief of the North-Western part of the Leningrad]. Proceedings of the Geological survey of USSR 117, Moscow-Leningrad. [in Russian.]

Markov, K.K., 1934: Pozdne- i poslelednikovaya istoriya okrestnostei Leningrada na phone pozdnei poslelednikovoi istorii Baltiki [Late Pleistocene and Holocene history of the Leningrad Region and the Baltic Sea]. Trudy komissii po izucheniyu tchetverticnogo perioda IV, iss. 1, 5-70. [in Russian with German summary].

Miettinen, A., 2002: Relative sea-level changes in the eastern part of the Gulf of Finland during the last 8000 years. Annales Academiae Scientiarum Fennicae, Geologica-Geographica 162. 102 pp.

Moore, P.D., Webb, J.A. \& Collinson, M.E., 1991: Pollen Analysis. Blackwell Scientific Publications, Oxford. $216 \mathrm{pp}$.

Mörner, N-A., 1969: The Late Quaternary history of the Kattegatt Sea and the Swedish West Coast: Deglaciation, shorelevel displacement, isostasy and eustasy. Sveriges Geologiska Undersökning C 640. $487 \mathrm{pp}$.

Olsson, I.U. 1980: Content of ${ }^{14} \mathrm{C}$ in marine mammals from northern Europe. Radiocarbon 22, 662-675.

Perttilä, P. \& Savchuk, O., 1996: State of the marine environments of the Baltic Sea regions. Gulf of Finland. 4.2.1. Hydrography. Third Periodic Assessment of the State of the Marine Environment of the Baltic Sea. Lycos.

Ramsay, W., 1920: Litorinagränsen i sydliga Finland. Geologiska Föreningens i Stockholm Förhandlingar 42, 243-263.

Ramsay, W., 1926: Nivåförändringar och stenåldersbosättning i det baltiska området. Fennia 47:4. 67 pp.

Raukas, A., 1991: Transgressions of the Baltic Sea and the pecularities of the formation of transgressive coastal deposits. Quaternaire 2, 3, 4, 126-130.

Sandgren, P. \& Snowball, I.F. 2001: Late Weichselian shore displacement on the Kullen peninsula in northwest Skåne, southern Sweden. Boreas 30, 115-130.

Sauramo, M., 1947: Studier över de senglaciala nivåförändringarna i Fennoscandia. Geologiska Föreningens $i$ Stockholm Förhandlingar 69, 79-108.

Simonsen, R. 1962: Untersuchungen zur Systematik und Ökologie der Bodendiatomeen der westlichen Ostsee. Intern. Rev. Hydrobiol. Syst. Beih. $1,1-144$.

Snowball, I.F. \& Thompson, R. 1990: A mineral magnetic study of Holocene sedimentation in Lough Catherine, Northern Ireland. Boreas 19, 127-146.

Stuiver, M., Reimer, P. J., Bard, E., Beck, J.W., Burr, G.S., Hughen, K.A., Kromer, B., McCormac, G., van der Plicht, J. \& Spurk, M., 1998: INTCAL98 Radiocarbon age calibration $24000-0$ cal. BP. Radiocarbon 40, 1041-1083.

Wasylikowa, K., 1986: Analysis of fossil fruits and seeds. In Berglund, B.E. (ed.): Handbook of Holocene Palaeoecology and Palaeohydrology, 571-590. John Wiley \& Sons.

Veski, S. 1988: Vegetation history, human impact and palaeogeography of west Estonia. Pollen analytical studies of lakes and bogs. Striae 38, 1-119.

Westman, P., Wastegård, S., Schoning, K., Gustafsson, B. \& Omstedt, A., 1999: Salinity change in the Baltic Sea during the last 8,500 years: evidence, causes and models. Svensk Kärnbränslehantering (SKB), Technical Report TR-99-38, 1-52.

Yu, S.-Y., 2003a: Centennial-scale cycles in middle Holocene sea level along the southeastern Swedish Baltic coast. GSA Bulletin 115, 1404-1409.

Yu, S.-Y., 2003b: The Littorina transgression in southeastern Sweden and its relation to midHolocene climate variability. LUNDQUA Thesis 51, Lund University, Lund, Sweden. $22 \mathrm{pp}$.

Znamenskaya, O.M., Vishnevskaya, E.M., Kleimenova, G.I., Malakhovsky, D.B., 1980: Pamyatnik nezhivoi prirody Leningradskoi oblasti - obnazhenie na Tchernoi rechke (po palinologicheskim i diatomovym issledovaniyam) [Monument of the lifeless nature of the Leningrad region - the outcrop River Tchernaya (based on polen and diatom data)]. Problemy okruzhayushei sredy. Mezhvuzovskii sbornik. LGU, Leningrad, 133-155. [in Russian]. 


\section{Appendix}

Radiocarbon dates. For calibration procedure see text.

\begin{tabular}{|c|c|c|c|c|c|c|}
\hline Depth (m) & Dated material & Cal. yr BP $(2 \sigma)$ & Cal. yr BP $(1 \sigma)$ & Cal. method & & \\
\hline \multicolumn{7}{|l|}{ Core LB1-01 } \\
\hline $3.175-3.275$ & LuA-4883 & gyttja & $940 \pm 115$ & $1100-650$ & $950-730$ & atm. \\
\hline $7.29-7.33$ & Poz-1382 & clayey fi. detr. gy. & $5175 \pm 45$ & $6200-5400$ & $5920-5600$ & marin \\
\hline $8.01-8.05$ & Poz-1371 & clayey fi. detr. gy. & $5455 \pm 45$ & $6450-5700$ & $6260-5920$ & marin \\
\hline $8.71-8.75$ & Poz-1372 & clayey fi. detr. gy. & $5990 \pm 40$ & $7200-6250$ & $\begin{array}{l}6860-6820 \\
6810-6450\end{array}$ & marin \\
\hline $9.425-9.475$ & LuA-4882 & clay gyttja & $5375 \pm 95$ & $6400-5600$ & $\begin{array}{l}6200-5850 \\
5830-5760\end{array}$ & marin \\
\hline $9.49-9.53$ & Poz-1391 & clayey fi. detr. gy. & $6630 \pm 45$ & $7700-7000$ & $\begin{array}{l}7560-7530 \\
7520-7240\end{array}$ & marin \\
\hline $10.29-10.33$ & Poz-1316 & clayey fi. detr. gy. & $7110 \pm 40$ & $8150-7500$ & $7940-7660$ & marin \\
\hline $10.525-10.575$ & LuA-4881 & gyttja & $7135 \pm 95$ & $8170-7750$ & $\begin{array}{l}8110-8090 \\
8030-7840\end{array}$ & atm. \\
\hline $10.79-10.83$ & Poz-1317 & clayey fi. detr. gy. & $8670 \pm 50$ & $\begin{array}{l}9870-9850 \\
9830-9810 \\
9780-9530\end{array}$ & $9690-9540$ & atm. \\
\hline $11.375-11.425$ & LuA-4880 & clay gyttja. & $9565 \pm 110$ & $11200-10550$ & $11110-10740$ & atm. \\
\hline \multicolumn{7}{|l|}{ Core LB2-01 } \\
\hline $1.76-1.80$ & Poz-1315 & fi. detr. gy. & $1450 \pm 30$ & $1410-1290$ & $\begin{array}{l}1385-1380 \\
1370-1360 \\
1355-1300\end{array}$ & atm. \\
\hline $2.08-2.12$ & LuA-5291 & fi. detr. gy. & $1810 \pm 95$ & $1950-1520$ & $\begin{array}{l}1870-1840 \\
1830-1610\end{array}$ & atm. \\
\hline $3.00-3.04$ & LuA-5290 & fi. detr. gy. & $3315 \pm 100$ & $3830-3350$ & $\begin{array}{l}3690-3660 \\
3650-3440 \\
3430-3410\end{array}$ & atm. \\
\hline $4.00-4.04$ & LuA-5289 & fi. detr. gy. & $4250 \pm 95$ & $5050-4400$ & $\begin{array}{l}4960-4930 \\
4880-4780 \\
4770-4610 \\
4600-4570\end{array}$ & atm. \\
\hline $6.65-6.68$ & LuA-5195 & fi. detr. gy. & $6530 \pm 90$ & $7650-6850$ & $\begin{array}{l}7470-7080 \\
7070-7030\end{array}$ & marin \\
\hline $8.58-8.60$ & LuA-5194 & fi. detr. gy. & $7185 \pm 85$ & $8180-7830$ & $\begin{array}{l}8450-8140 \\
8120-8080 \\
8050-7930 \\
7900-7870\end{array}$ & atm. \\
\hline $9.12-9.16$ & LuA-5193 & fi. detr. gy. & $7600 \pm 85$ & $\begin{array}{l}8590-8570 \\
8150-8190\end{array}$ & $\begin{array}{l}8540-8530 \\
8520-8500 \\
8480-8320 \\
8260-8250 \\
8240-8210\end{array}$ & atm. \\
\hline $9.28-9.32$ & LuA-5192 & fi. detr. gy. & $6360 \pm 85$ & $\begin{array}{l}7430-7150 \\
7130-7020\end{array}$ & $7420-7210$ & atm. \\
\hline \multicolumn{7}{|l|}{ Core LL3-01 } \\
\hline $3.20-3.24$ & LuA-5288 & fi. detr. gy. & $5545 \pm 95$ & $6650-5750$ & $\begin{array}{l}6350-6330 \\
6320-5940\end{array}$ & marin \\
\hline $3.88-3.92$ & LuA-5287 & fi. detr. gy. & $6360 \pm 100$ & $7500-6650$ & $7310-6880$ & marin \\
\hline $4.18-4.20$ & LuA-5275 & wood & $7030 \pm 85$ & $7980-7670$ & $7940-7750$ & atm. \\
\hline $4.26-4.28$ & Poz- 1374 & si. clay gy. & $7400 \pm 50$ & $8400-7750$ & $\begin{array}{l}8290-8260 \\
8210-7920 \\
7890-7880\end{array}$ & marin \\
\hline $4.62-4.64$ & Poz- 1373 & si. clay gy. & $7280 \pm 50$ & $8350-7600$ & $8130-7790$ & marin \\
\hline $4.68-4.70$ & LuA-5274 & wood & $6795 \pm 95$ & $7830-7460$ & $\begin{array}{l}7730-7560 \\
7530-7510\end{array}$ & atm. \\
\hline \multicolumn{7}{|l|}{ Core LK1-03 } \\
\hline $2.47-2.49$ & Poz-2892 & moss-sedge peat & $6990 \pm 40$ & $\begin{array}{l}7940-7890 \\
7880-7960\end{array}$ & $\begin{array}{l}7920-7900 \\
7860-7750\end{array}$ & atm. \\
\hline $2.89-2.90$ & Poz-2893 & moss-sedge peat & $7120 \pm 40$ & $8030-7830$ & $\begin{array}{l}7980-7920 \\
7900-7860\end{array}$ & atm. \\
\hline $3.24-3.25$ & Poz-2895 & moss-sedge peat & $7520 \pm 40$ & $\begin{array}{l}8400-8280 \\
8270-8190\end{array}$ & $\begin{array}{l}8390-8320 \\
8260-8210\end{array}$ & atm. \\
\hline \multicolumn{7}{|l|}{ Core LG1-03 } \\
\hline $7.98-8.00$ & Poz-2905 & fi. detr. gy. & $3645 \pm 35$ & $4090-3860$ & $\begin{array}{l}4070-4040 \\
3990-3890\end{array}$ & atm. \\
\hline $8.05-8.07$ & Poz-2906 & silty gy. & $4200 \pm 35$ & $\begin{array}{l}4840-4780 \\
4770-4610 \\
4600-4580\end{array}$ & $\begin{array}{l}4840-4800 \\
4770-4700 \\
4680-4650\end{array}$ & atm. \\
\hline $8.21-8.23$ & Poz 2907 & silty gy. & $5020 \pm 30$ & $5950-5250$ & $\begin{array}{l}5870-5810 \\
5760-5440\end{array}$ & marin \\
\hline $8.29-8.31$ & Poz-2953 & silty gy. & $6220 \pm 35$ & $7350-6550$ & $\begin{array}{l}7150-7110 \\
7100-6750\end{array}$ & marin \\
\hline $8.41-8.43$ & Poz-5964 & silty gy. & $6850 \pm 50$ & $\begin{array}{l}7790-7770 \\
7760-7580\end{array}$ & $7740-7610$ & atm. \\
\hline
\end{tabular}

${ }^{*}$ LuA-samples are from core LB1-98 and Poz-samples are from core LB1-01. 